\title{
Caracterização das ações de alunos e professor que exploram objetos de
} aprendizagem em aulas de Matemática

\author{
Actions characterization of students and teacher who explore learning objects in Mathematic
}

classes

Caracterización de las acciones de estudiantes y el profesor que exploran objetos de aprendizaje en las clases de Matemáticas

Recebido: 20/01/2021 | Revisado: 23/01/2021 | Aceito: 25/01/2021 | Publicado: 01/02/2021

Fabio Roberto Vicentin

ORCID: https://orcid.org/0000-0002-9742-7494 Secretaria de Estado da Educação do Paraná, Brasil E-mail: farovi@ seed.pr.gov.br

Marinez Meneghello Passos

ORCID: https://orcid.org/0000-0001-8856-5521 Universidade Estadual de Londrina, Brasil E-mail: marinezpassos@uel.br Sergio de Mello Arruda

ORCID: https://orcid.org/0000-0002-4149-2182 Universidade Estadual de Londrina, Brasil E-mail: sergioarruda@uel.br

\begin{abstract}
Resumo
Neste artigo apresentamos os resultados de uma pesquisa que buscou caracterizar as ações de alunos e professor em aulas de Matemática em que os sujeitos investigados exploraram um objeto de aprendizagem. Os dados, coletados por intermédio de notas de campo e de gravações em vídeo, foram obtidos no decurso de três aulas de Matemática com alunos dos Anos Finais do Ensino Fundamental. Assumimos, nesta pesquisa, a Análise de Conteúdo como uma proposta teórica utilizada como método de coleta e análise de dados qualitativos, sendo que por meio de seus procedimentos evidenciamos: 20 categorias e 54 subcategorias de ações docentes; e 30 categorias e 91 subcategorias de ações discentes. Ao compararmos as categorias que encontramos com aquelas emergidas de investigações decorrentes de aulas expositivas e de aulas baseadas em materiais didáticos manipuláveis, percebemos que as aulas fundamentadas no uso de objetos de aprendizagem produziram maior quantidade de categorias de ações docentes e discentes, além de identificarmos a existência de algumas categorias semelhantes nesses diferentes tipos de aula.
\end{abstract}

Palavras-chave: Ensino; Tecnologias digitais; Objeto de aprendizagem; Ação docente; Ação discente.

\begin{abstract}
In this article we present the results of a research that sought to characterize the actions of students and teacher in Mathematic classes in which the subjects investigated explored a learning object. The datas, collected through field notes and video recordings, were obtained during the course of three mathematic classes with students from the Final Years of Elementary School. Content Analysis was used as a method of data collection and analysis, and through its procedures were obtained: 20 categories and 54 subcategories of teaching actions; and 30 categories and 91 subcategories of students actions. When comparing the categories we found with those that emerged from investigations resulting from lecture classes and classes based on manipulative didatic materials, we realized that classes based on the use of learning objects produced a greater number of categories of teacher and students actions; we also identified the existence of some similar categories in these different types of classes.
\end{abstract}

Keywords: Teaching; Digital technologies; Learning object; Teacher action; Student action.

\section{Resumen}

En este artículo presentamos los resultados de una investigación cuyo objetivo fue caracterizar las acciones de los estudiantes y el profesor en las clases de matemáticas en las que los sujetos investigados exploraron uno objeto de aprendizaje. Los datos, recolectados a través de notas de campo y mediante grabación de video, se obtuvieron durante tres clases de matemáticas con estudiantes de los últimos años de la escuela primaria. En esta investigación, asumimos el Análisis de Contenido como una propuesta teórica utilizada como método de recolección y análisis de datos cualitativos, y a través de sus procedimientos mostramos: 20 categorías y 54 subcategorías de acciones docentes; y 30 categorías y 91 subcategorías de acciones estudiantiles. Al comparar las categorías que encontramos con las que 
surgieron de las investigaciones resultantes de las clases expositivas y las clases basadas en materiales didácticos manipulativos, nos dimos cuenta de que las clases basadas en el uso de objetos de aprendizaje producían un mayor número de categorías de acciones docentes y estudiantiles, además de identificar la existencia de algunas categorías similares en estos diferentes tipos de clases.

Palabras clave: Ensenãnza; Tecnologías digitales; Objeto de aprendizaje; Acción docente; Acción estudiantil.

\section{Introdução}

Nos últimos anos mobilizamo-nos para compreender a respeito da inserção de recursos tecnológicos nos processos educacionais, mais especificadamente, focados no ensino e na aprendizagem de conteúdos matemáticos.

Em nossas pesquisas mais recentes temos buscado caracterizar as ações de alunos e professor no decurso da exploração de objetos de aprendizagem (OA), em aulas de Matemática, fazendo uso da lousa digital (LD). Tais investigações levaram-nos a conhecer, descrever e analisar o contexto educacional em que, nós pesquisadores, estamos inseridos.

Por conseguinte, a investigação cujos resultados apresentamos neste artigo decorreu da seguinte questão de pesquisa: Quais são as ações de alunos e professor de Matemática, em sala de aula, no decorrer da exploração de um OA na LD?

Neste cenário propusemo-nos a caracterizar as ações docentes e as discentes, em situações de sala de aula, no decorrer da exploração de um OA, isto é, em aulas fundamentadas no uso de tecnologias, tendo a ação como protagonista de um movimento investigativo que integra um programa de pesquisa que procura estudar a ação docente, entendida como a ação que o professor realiza em sala de aula, tendo em vista o ensinar e o aprender; e a ação discente como sendo a atividade que o aluno desenvolve em sala de aula, visando aprender o saber escolar.

Nas próximas seções trazemos: a descrição dos procedimentos metodológicos; as fundamentações teóricas a respeito do uso das tecnologias digitais (TD) e dos OA na Educação Matemática; os OA estudados e o repositório de objeto de aprendizagem (ROA) em que esses recursos podem ser localizados, bem como uma sucinta descrição acerca do recurso elegido para a análise dos dados; a apresentação e análise dos dados; considerações acerca do que os dados nos indicaram e as conclusões que o fenômeno investigado nos propiciou.

\section{Procedimentos Metodológicos}

As aulas foram planejadas no início do segundo semestre de 2019 pelos pesquisadores e implementadas no fim do mesmo semestre, a alunos do Ensino Fundamental II e do Ensino Médio de um colégio da rede pública estadual paranaense.

Foram filmadas oito aulas - de 50 minutos cada - e acompanhadas por meio de anotações em um caderno de campo elaborado pelos pesquisadores, assegurando o registro das ações dos alunos e do professor de Matemática. Procedimentos que produziram uma quantidade expressiva de dados, motivo pelo qual decidimos por trazer os resultados da aplicação (ocorrida em dezembro de 2019 e com quatorze alunos do $7^{\circ}$ ano do Ensino Fundamental) de um dos objetos de aprendizagem (o OA "Construtor de área") explorado e estudado no decurso de três aulas.

Para a realização das tarefas da atividade propiciada pelo OA, foi solicitado aos alunos que se organizassem em duplas (sete, no total), cujo intuito foi o de fomentar a interação entre eles.

No que diz respeito à abordagem metodológica utilizada nesta pesquisa, nossa opção foi pela qualitativa determinada pelos instrumentos de coleta de dados, ou seja, por meio de gravações em vídeo e notas de campo realizadas pelos pesquisadores; pelo método de análise que esteve pautado nos procedimentos da Análise de Conteúdo (AC), como concebido por Moraes (1999), na interpretação dos dados para a caracterização das ações dos sujeitos investigados. No que se refere a pesquisa qualitativa, segundo a compreensão de Flick (2009, p. 25) "os métodos qualitativos consideram a comunicação do pesquisador em campo como parte explícita da produção de conhecimento".

Para Flick (2009) os aspectos essenciais da pesquisa qualitativa consistem na apropriabilidade de métodos e teorias 
convenientes; no reconhecimento e na análise das perspectivas dos participantes e sua diversidade; na reflexão do pesquisador a respeito de suas pesquisas como parte do processo de produção de conhecimento; e na variedade de abordagens e de métodos. Ainda, segundo Flick (2009, p. 25):

[...] os métodos qualitativos consideram a comunicação do pesquisador em campo como parte explícita da produção de conhecimento, em vez de simplesmente encará-la como uma variável a interferir no processo. A subjetividade do pesquisador, bem como daqueles que estão sendo estudados, tornam-se parte do processo de pesquisa. As reflexões dos pesquisadores sobre suas próprias atitudes e observações em campo, suas impressões, irritações, sentimentos, etc., tornam-se dados em si mesmos, constituindo parte da interpretação e são, portanto, documentadas em diários de pesquisa ou em protocolos de contexto.

Em conformidade à compreensão de Moraes (1999), a AC constitui-se em uma metodologia de pesquisa pautada na descrição e interpretação do conteúdo de toda classe de documentos e textos. Para isso, os dados coletados necessitam ser submetidos a um conjunto de mecanismos os quais apresentaremos, resumidamente, em cinco etapas. (1) Preparação das informações: consiste em escolher quais são os textos - por meio da leitura de todo o material a ser submetido à análise - que estão de acordo com os objetivos da investigação (seleção do corpus $^{1}$ ) e estabelecer códigos - constituído por letras ou números - que possibilitem identificar com agilidade cada elemento da amostra de depoimentos; (2) Unitarização: refere-se ao processo de reler os materiais, definir as unidades de análise - elemento unitário de conteúdo a ser submetido à classificação e isolar cada uma delas; (3) Categorização: procedimento de agrupamento de dados considerando a parte comum existente entre eles, realizado por semelhança ou analogia, de acordo com os critérios - que podem ser semânticos, sintáticos ou léxicos - previamente estabelecidos ou definidos no processo; (4) Descrição: produção de um texto como resultado da análise que destacará a compreensão do fenômeno em questão, sua validade como pesquisa e seus resultados; (5) Interpretação: consiste em um movimento de exploração das unidades de análise baseado em categorias a priori ou emergentes dos dados.

Fizemos uso do critério de pertinência para o agrupamento de uma unidade de análise para uma categoria, e o que levamos em consideração foi a relação de semelhança entre a unidade e os significantes da categoria correspondente que emergiram dos dados da situação pesquisada. Porém, também, sem deixarmos de considerar, preliminarmente, como a priori, as categorias encontradas em investigações que concluímos e em pesquisas realizadas por outros autores, apresentadas no Quadro 1.

\footnotetext{
1 “[...] o conjunto dos documentos tidos em conta para serem submetidos aos procedimentos analíticos” (Bardin, 2011, p. 126).
} 
Quadro 1 - Quadro descritivo das ações docentes e (ou) discentes.

\begin{tabular}{|c|c|c|c|}
\hline $\begin{array}{c}\text { Metodologias e materiais } \\
\text { empregados/Autores }\end{array}$ & $\begin{array}{c}\text { Modalidades de } \\
\text { Ensino }\end{array}$ & $\begin{array}{c}\text { Categorias }^{2} \text { de ações } \\
\text { docentes }\end{array}$ & $\begin{array}{c}\text { Categorias de ações } \\
\text { discentes }\end{array}$ \\
\hline $\begin{array}{l}\text { Tradicional (aulas } \\
\text { expositivas). } \\
\text { (Andrade \& Arruda, 2017) }\end{array}$ & $\begin{array}{l}\text { Anos Finais do Ensino } \\
\text { Fundamental. }\end{array}$ & $\begin{array}{l}\text { Burocrático-Administrativa, } \\
\text { Escreve, Espera, Explica. }\end{array}$ & Não pesquisadas. \\
\hline $\begin{array}{l}\text { Aula fundamentada em } \\
\text { atividades com o uso de } \\
\text { materiais didáticos } \\
\text { manipuláveis. } \\
\text { (Dias, Arruda, Oliveira \& } \\
\text { Passos, 2017) }\end{array}$ & $\begin{array}{l}\text { Anos Finais do Ensino } \\
\text { Fundamental. }\end{array}$ & $\begin{array}{l}\text { Ameaçar, Chamar, Deslocar, } \\
\text { Escrever, Esperar, Explicar, } \\
\text { Justificar, Organizar, Pedir, } \\
\text { Perguntar, Providenciar, } \\
\text { Reprovar, Responder e } \\
\text { Supervisionar. }\end{array}$ & Não pesquisadas. \\
\hline $\begin{array}{l}\text { Tradicional (aulas } \\
\text { expositivas). } \\
\text { (Benicio, Arruda \& Passos, } \\
2019 \text { ) }\end{array}$ & $\begin{array}{l}\text { Ensino Médio e Técnico } \\
\text { Integrado. }\end{array}$ & Não pesquisadas. & $\begin{array}{l}\text { Dispersa, Espera, Interage } \\
\text { com a Professora, Interage } \\
\text { com os Colegas, Organiza, } \\
\text { Outras Ações, Pratica. }\end{array}$ \\
\hline $\begin{array}{l}\text { Aulas fundamentadas na } \\
\text { utilização de objetos de } \\
\text { aprendizagem na lousa } \\
\text { digital. } \\
\text { (Vicentin, Passos \& Arruda, } \\
\text { 2019) }\end{array}$ & $\begin{array}{l}\text { Anos Finais do Ensino } \\
\text { Fundamental. }\end{array}$ & $\begin{array}{l}\text { Auxilia, Chama a atenção, } \\
\text { Comenta, Coordena, } \\
\text { Demonstra, Discute, Espera, } \\
\text { Explica, Expõe, Incentiva, } \\
\text { Liga, Presta atenção, Projeta, } \\
\text { Solicita, Pergunta, Realiza, } \\
\text { Responde, Sugere, Valoriza. }\end{array}$ & $\begin{array}{l}\text { Arrasta, Arrisca, Auxilia, } \\
\text { Comemora, Deixa, Discute, } \\
\text { Escuta, Espera, Explora, } \\
\text { Observa, Organiza, Participa, } \\
\text { Pergunta, Presta atenção, } \\
\text { Realiza, Recebe auxílio, } \\
\text { Resolve, Responde, } \\
\text { Seleciona, Solicita auxílio, } \\
\text { Solicita explicação, Utiliza. }\end{array}$ \\
\hline $\begin{array}{l}\text { Aulas fundamentadas na } \\
\text { utilização de objetos de } \\
\text { aprendizagem na lousa } \\
\text { digital. } \\
\text { (Vicentin, Passos \& Arruda, } \\
\text { 2020) }\end{array}$ & $\begin{array}{l}\text { Anos Finais do Ensino } \\
\text { Fundamental. }\end{array}$ & $\begin{array}{l}\text { Auxilia, Calibra, Comenta, } \\
\text { Coordena, Demonstra, } \\
\text { Discute, Espera, Explica, } \\
\text { Expõe, Incentiva, Indica, } \\
\text { Liga, Pergunta, Presta } \\
\text { atenção, Projeta, Realiza, } \\
\text { Resolve, Responde, Solicita, } \\
\text { Sugere, Valoriza. }\end{array}$ & $\begin{array}{l}\text { Aceita ou não, Aguarda, } \\
\text { Arrisca, Apaga, Arrasta, } \\
\text { Auxilia, Busca, Comemora, } \\
\text { Confere, Descobre, Desenha, } \\
\text { Discute, Escreve, Escuta, } \\
\text { Espera, Fala, Indica, Inicia, } \\
\text { Justifica, Mexe, Observa, } \\
\text { Organiza, Participa, Percebe, } \\
\text { Pergunta, Presta atenção, } \\
\text { Realiza, Responde, } \\
\text { Seleciona, Sente interesse, } \\
\text { Solicita auxílio, Solicita } \\
\text { explicação, Sugere, Tira } \\
\text { selfie, Utiliza. }\end{array}$ \\
\hline
\end{tabular}

Fonte: Andrade e Arruda (2017); Dias, Arruda, Oliveira e Passos (2017); Benicio, Arruda e Passos (2019); Vicentin, Passos e Arruda $(2019,2020)$.

O tipo de análise utilizada nesta investigação foi a categorial, uma vez que se estabelece "por operações de desmembramento do texto em unidades, em categorias segundo reagrupamentos analógicos” (Bardin, 2011, p. 201). Em razão disso, a categorização ocorreu na medida em que evidenciamos as unidades de análise referentes às ações dos alunos e do professor.

Mediante tal contexto, temos verificado que tanto as ações de alunos e de professores, geralmente, modificam de acordo com as metodologias e os materiais empregados, o que nos tem impulsionado a investigar as ações docentes e as discentes em atividades fundamentadas na utilização de objetos de aprendizagem na LD, distinguindo-se das pesquisas já realizadas por Andrade e Arruda (2017); Dias, Arruda, Oliveira e Passos (2017); e Benicio, Arruda e Passos (2019).

No sentido de manter o sigilo com relação aos sujeitos envolvidos nesta investigação, os nomes dos alunos e do colégio foram suprimidos. Informamos também que: os alunos e seus responsáveis estavam cientes da participação na pesquisa

\footnotetext{
${ }^{2}$ Para a nomeação das categorias, os autores fizeram uso de verbos de ação, indicando as ações realizadas pelos professores. $\mathrm{O}$ mesmo critério foi adotado para a nomeação das categorias de ações discentes (coluna 4).
} 
e o colégio foi cadastrado na Plataforma Brasil ${ }^{3}$.

\section{Referencial Teórico: as Tecnologias Digitais no Ensino de Matemática, os Objetos de Aprendizagem Explorados e seu Repositório}

$\mathrm{Na}$ atualidade estamos vivendo em uma sociedade em que as tecnologias têm invadido e integrado o cotidiano dos indivíduos. Na concepção de Kenski (2003, p. 21) "a evolução tecnológica não se restringe apenas aos novos usos de determinados equipamentos e produtos. Ela altera comportamentos". A mesma autora ainda afirma que "o homem transita culturalmente mediado pelas tecnologias que lhe são contemporâneas. Elas transformam suas maneiras de pensar, sentir, agir. Mudam também suas formas de se comunicar e de adquirir conhecimentos" (Kenski, 2003, p. 21).

Na era da informação, comportamentos, práticas, informações e saberes se alteram com extrema velocidade. Um saber ampliado e mutante caracteriza o atual estágio do conhecimento na atualidade. Essas alterações refletem-se sobre as tradicionais formas de pensar e fazer educação. Abrir-se para novas educações - resultantes de mudanças estruturais nas formas de ensinar e aprender possibilitadas pela atualidade tecnológica - é o desafio a ser assumido por toda a sociedade (Kenski, 2003, p. 27).

Em uma sociedade cada vez mais tecnológica, na visão de Kalinke e Motta (2019, p. 10) "as escolas têm um importante papel no desenvolvimento de novas tecnologias que incorporem as tecnologias digitais (TD)" e "as tornem de uso rotineiro em atividades educacionais". Afirmam ainda que algumas mudanças, decorrentes desses impactos, "requerem das escolas o enriquecimento de suas práticas pedagógicas com bases em métodos educacionais que satisfaçam esta nova realidade" (Kalinke \& Motta, 2019, p. 10).

As tecnologias digitais, de acordo com a concepção de Ponte (1995 apud Silva, 2015, p. 13), e que também assumimos, trazem para o ensino e a aprendizagem da Matemática "uma demonstração prática de envolver os alunos em atividade matemática intensa e significativa", oportunizando o desenvolvimento de atitudes positivas quanto a essa disciplina e "uma visão muito mais completa de sua verdadeira natureza" (Ponte, 1995 apud Silva, 2015, p. 13).

Por conseguinte, salientamos que temos buscado incorporar as tecnologias digitais nos processos de ensino e de aprendizagem em nossas aulas de Matemática por conhecer algumas de suas potencialidades e por estarmos de acordo com a concepção de Silva (2015) de que a utilização de tecnologias de informação e comunicação integradas às práticas de ensino, "além de irem ao encontro de uma tendência mundial, tornam a aula mais atrativa ao aluno e menos monótona do que quando ofertada de forma tradicional, pois instrumentalizam os alunos, tornando-os aptos a suprirem as demandas tecnológicas presentes e futuras" (Silva, 2015, p. 12).

Os processos de ensino e de aprendizagem não são estáticos, pois vivenciamos um período de intensas mudanças. O modelo tradicional de ensino está sendo posto à prova diante dos avanços tecnológicos. As novas tecnologias têm influenciado, em boa parte, o nosso modo de pensar e de agir (Pereira \& Araújo, 2020, p. 6).

No que concerne aos materiais didáticos, Kalinke e Motta (2019) explicitam que existe um movimento amplo, até mesmo no Brasil, de aproximação dos recursos tecnológicos com os livros didáticos impressos, havendo uma popularização dos materiais didáticos digitais e a substituição dos materiais impressos pelos digitais, originando os livros digitais "que pouco, ou nenhum valor tecnológico, agregam aos processos educacionais. Não há o uso de recursos tecnológicos de tal modo que

\footnotetext{
${ }^{3}$ No projeto de pesquisa intitulado "O ensino e a aprendizagem de ciências e matemática em sala de aula e em ambientes informais", coordenado por Sergio de Mello Arruda e aprovado pelo Comitê de Ética (Número do CAAE: 57663716.9.0000.5231. Número do Parecer: 1.666.360).
} 
novas possibilidades de apresentação dos conteúdos educacionais sejam exploradas” (Kalinke \& Motta, 2019, p. 10), nem sequer novas práticas e metodologias sejam inseridas nas salas de aula.

Os materiais didáticos digitais, contudo, podem agregar recursos e possibilidades interessantes para a aprendizagem da Matemática, particularmente quando exploram simulações, o uso de sensores, vídeos interativos e programações individualizadas. Estes, entre outros recursos, permitem que diferentes possibilidades cognitivas sejam exploradas e novas formas de aprendizagem sejam oportunizadas. Estes recursos podem ser incorporados nas práticas de ensino pelo uso dos OA, que também são conhecidos como objetos de aprendizagem multimídia, objetos educacionais digitais, objetos virtuais de aprendizagem e outras denominações similares (Kalinke \& Motta, 2019, pp. 10-11).

O uso dos OA, segundo Kalinke e Motta (2019) tem potencial para modificar a dinâmica das aulas, introduzindo novas alternativas de trabalho pedagógico, "que façam uso de exploração, simulação e interatividade, com atividades nas quais a busca pelo conhecimento seja uma constante" (p. 11). Diversos outros autores, que estudam essa temática, segundo Kalinke e Motta (2019), apontam que os OA podem vir a "agregar possibilidades inovadoras ao ensino de Matemática" (p. 11). Ainda, a utilização dos OA podem "auxiliar nos processos de aprendizagem, nos quais o aluno passa a ser o foco, tornando-se construtor de novos conhecimentos" (Kalinke \& Motta, 2019, p. 13). Finalmente, apontamos mais uma das vantagens do uso de OA no decurso de aulas de Matemática que:

[...] deve-se ao fato da tecnologia digital estar presente no dia a dia de alguma forma em todos os alunos, proporcionando uma melhor aceitação por parte desses com relação ao seu uso, visto que, trata-se de um recurso tecnológico, e que muitos já estão de certa maneira familiarizados com o uso de alguma tecnologia no seu cotidiano (Ferreira, Oliveira \& Coelho Neto, 2018, p. 5).

Ressaltamos, ainda, que nos mantivemos envolvidos, nos últimos anos, em compreender e utilizar a LD no ensino e na aprendizagem da Matemática por oferecer "a opção aos professores de criar ambientes de aprendizagem nos quais os alunos podem construir seu próprio conhecimento" (López, 2010 apud Navarro \& Kalinke, 2018, p. 116).

Dentre os muitos ROA conhecidos, elegemos o repositório PhET Simulações Interativas - do qual selecionamos três OA ("Construtor de Área"; "Frações: igualdade"; "Resistência em um fio"), porém, apresentamos, neste artigo, resultados da aplicação do OA “Construtor de Área” - sobretudo pelo motivo de estar em conformidade com a classificação de Battistella et al. (2009, p. 3), na qual sustentam que os objetos de aprendizagem interativos "necessitam do input do usuário para serem utilizados" e são exploratórios por "permitirem alterar o estado do objeto para obter novas saídas e informações”.

O repositório PhET Simulações Interativas ${ }^{4}$ é mantido pela University of Colorado Boulder e disponibiliza simulações interativas - que podem ser utilizadas on-line e (ou) copiadas para um computador - relacionadas às áreas do conhecimento: Matemática e Ciências. Os recursos digitais disponíveis são livres para o uso por alunos e professores devido ao auxílio financeiro de patrocinadores, apoiadores do projeto PhET. A equipe proponente desse repositório é composta por professores, especialistas em multimídia e design, desenvolvedores de softwares e estudantes. Informamos ainda que nesse ROA são disponibilizados recursos para os seguintes níveis de ensino: Ensino Fundamental, Ensino Médio e Ensino Superior (Phet Interactive Simulations, 2019).

Quanto ao OA “Construtor de Área” o mesmo apresenta potencialidades para o estudo dos conteúdos matemáticos área, áreas fracionárias, perímetro e escala. Em relação aos objetivos de aprendizagem, os idealizadores desse OA informam que esse recurso oportuniza aos alunos: construir formas com certa área e (ou) perímetro; descrever a relação entre área e perímetro; determinar o fator de escala de formas semelhantes; encontrar a área de formas regulares (quadrados, retângulos e

${ }^{4}$ Localizado no endereço eletrônico: https://phet.colorado.edu/pt_BR/. 
triângulos) e irregulares; generalizar como a área e o perímetro alteram ao redimensionar formas (Phet Interactive Simulations, 2019).

Por último, informamos que esse OA é composto por duas atividades - Figura 1 - intituladas por "Explore" e "Jogo". A nossa opção foi pela atividade "Jogo" por proporcionar desafios (em seis níveis de dificuldade) e um ambiente visualmente atrativo com imagens e sons que são capazes de motivar e estimular o interesse, a atenção e a concentração do usuário.

Figura 1 - Tela inicial das duas atividades do OA "Construtor de Área"

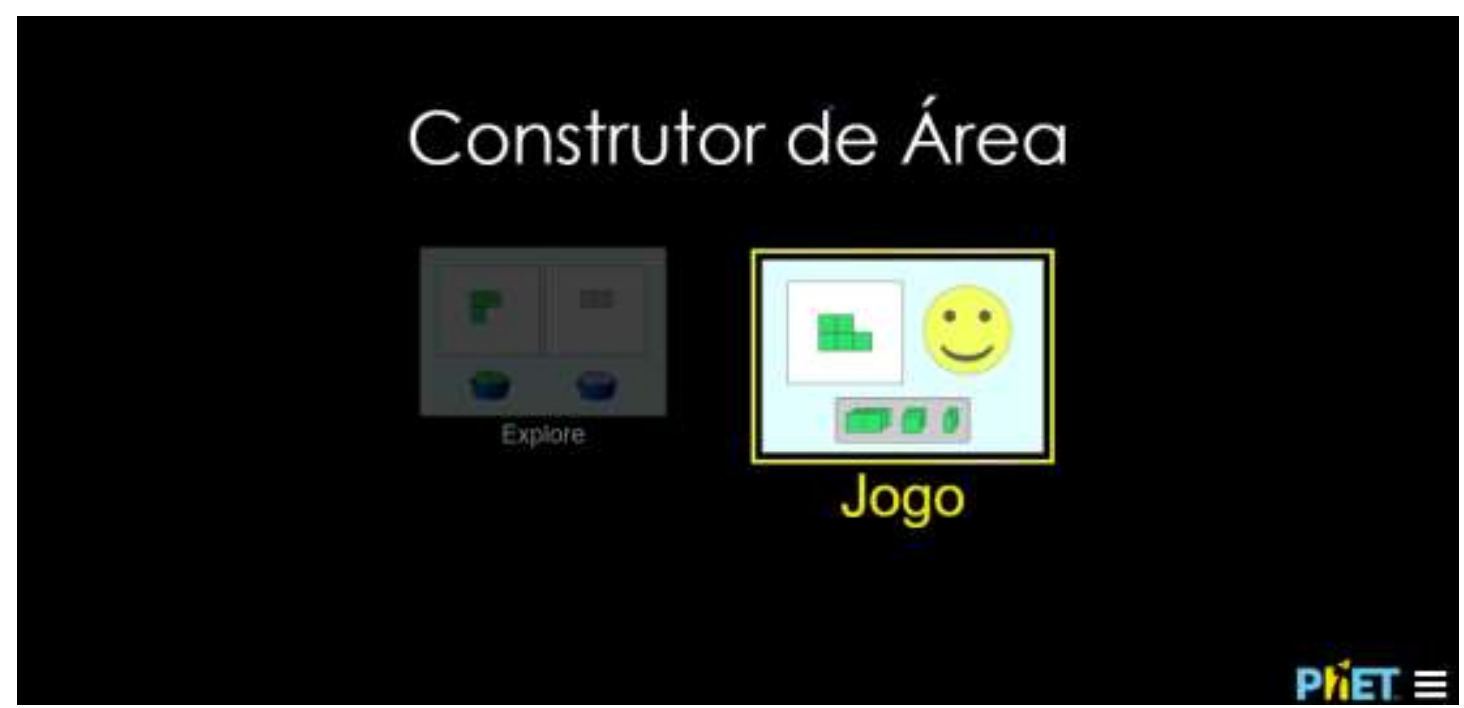

Fonte: PHET Interactive Simulations, University of Colorado Boulder, https://phet.colorado.edu (2019).

\section{Resultados e Discussões}

Nessa seção expomos os fragmentos de textos (nesse caso específico, aulas transcritas e registros de notas de campo) - apresentados como subcategorias de ações docentes e discentes - que revelaram as ações dos alunos e do professor diante da situação em que se encontravam, ou seja, durante a utilização de um OA na LD; agrupados por semelhança de sentidos em categorias ${ }^{5}$. Para a nomeação de tais categorias utilizamos verbos de ação, isto é, verbos que indicassem ações docentes, descritas no parágrafo que antecede cada quadro e ações discentes apresentadas nos quadros.

Pautando-nos, preliminarmente, nas 20 categorias de ações docentes (organizadas e apresentadas em ordem alfabética na linha 4 e coluna 3 do Quadro 1) que produziram 54 subcategorias, elaboramos 17 quadros apresentados na sequência com as ações discentes (30 categorias que geraram 91 subcategorias).

Descrevemos, no Quadro 2, informações a respeito das categorias e subcategorias de ações discentes decorrentes da categoria de ação docente 'Auxilia', que possui três subcategorias: 'Auxilia os alunos na atividade do OA', 'Auxilia os alunos nas técnicas de cálculo mental' e 'Auxilia os alunos nos conteúdos do OA'; que suscitaram as categorias de ações discentes observadas na coluna 1 e as subcategorias relacionadas a essas ações na coluna 2, todas dispostas em ordem alfabética.

\footnotetext{
${ }^{5} \mathrm{O}$ movimento de exploração das unidades de análise esteve fundamentado em categorias a priori e nas inferências dos pesquisadores com relação às unidades de análise das quais emergiram outras categorias.
} 
Quadro 2 - Categorias e subcategorias de ações discentes relativas à categoria 'Auxilia'.

\begin{tabular}{|c|c|}
\hline Categorias de ações discentes & Subcategorias de ações discentes \\
\hline Apaga & Apagam os registros do quadro negro. \\
\hline Arrasta & $\begin{array}{l}\text { Arrastam objetos com a caneta digital no modo 'interativo'. } \\
\text { Arrastam objetos com o mouse do ultrabook. }\end{array}$ \\
\hline Arrisca & Arriscam uma resposta para a atividade do OA. \\
\hline Auxilia & $\begin{array}{l}\text { Auxiliam o parceiro de dupla e os outros alunos na atividade do OA. } \\
\text { Auxiliam o parceiro de dupla e os outros alunos nos conteúdos do OA. }\end{array}$ \\
\hline Comemora & Comemoram os acertos. \\
\hline Confere & $\begin{array}{l}\text { Conferem a resposta da atividade do OA com a caneta digital no modo 'interativo'. } \\
\text { Conferem a resposta da atividade do OA com o mouse do ultrabook. }\end{array}$ \\
\hline Desenha & Desenham no quadro negro. \\
\hline Incentiva & $\begin{array}{l}\text { Incentivam o parceiro de dupla e os outros alunos a buscarem diferentes estratégias de } \\
\text { resolução para a atividade do OA. } \\
\text { Incentivam o parceiro de dupla e os outros alunos a realizarem a atividade do OA. }\end{array}$ \\
\hline Inicia & Iniciam a atividade do OA. \\
\hline Observa & Observam o parceiro de dupla e os outros alunos realizarem a atividade do OA. \\
\hline Pergunta & $\begin{array}{l}\text { Perguntam ao parceiro de dupla e aos outros alunos sobre a atividade do OA. } \\
\text { Perguntam ao parceiro de dupla e aos outros alunos sobre os conteúdos do OA. } \\
\text { Perguntam ao professor sobre a atividade do OA. } \\
\text { Perguntam ao professor sobre os conteúdos do OA. }\end{array}$ \\
\hline Presta atenção & $\begin{array}{l}\text { Prestam atenção na atividade do OA através da área de projeção da LD. } \\
\text { Prestam atenção na atividade do OA através da tela do ultrabook. }\end{array}$ \\
\hline Realiza & $\begin{array}{l}\text { Realizam a atividade do OA com a caneta digital no modo 'interativo'. } \\
\text { Realizam a atividade do OA com o mouse do ultrabook. } \\
\text { Realizam cálculos mentalmente. } \\
\text { Realizam cálculos no quadro negro. }\end{array}$ \\
\hline Responde & $\begin{array}{l}\text { Respondem aos questionamentos do parceiro de dupla e dos outros alunos sobre a } \\
\text { atividade do OA. } \\
\text { Respondem aos questionamentos do parceiro de dupla e dos outros alunos sobre os } \\
\text { conteúdos do OA. } \\
\text { Respondem aos questionamentos do professor sobre a atividade do OA. } \\
\text { Respondem aos questionamentos do professor sobre os conteúdos do OA. }\end{array}$ \\
\hline Seleciona & $\begin{array}{l}\text { Selecionam a atividade do OA com a caneta digital no modo 'interativo'. } \\
\text { Selecionam a atividade do OA com o mouse do ultrabook. } \\
\text { Selecionam a resposta da atividade do OA com a caneta digital no modo 'interativo'. } \\
\text { Selecionam a resposta da atividade do OA com o mouse do ultrabook. } \\
\text { Selecionam o nível de dificuldade da atividade do OA com a caneta digital no modo } \\
\text { 'interativo'. } \\
\text { Selecionam o nível de dificuldade da atividade do OA com o mouse do ultrabook. }\end{array}$ \\
\hline Solicita auxílio & $\begin{array}{l}\text { Solicitam auxílio ao professor sobre a atividade do OA. } \\
\text { Solicitam auxílio ao professor sobre os conteúdos do OA. }\end{array}$ \\
\hline Utiliza & U Utilizam diferentes estratégias de resolução para a atividade do OA. \\
\hline
\end{tabular}

Fonte: Autores.

As ações docentes, concernentes à categoria 'Auxilia', apresentadas no parágrafo anterior ao Quadro 2, são subcategorias que retratam a maneira como o professor auxiliou os alunos na atividade e nos conteúdos da atividade do OA.

Em virtude da referida categoria de ação docente, constatamos que os alunos desenvolveram trinta e sete diferentes ações - subcategorias de ações discentes (coluna 2 do Quadro 1) - alocadas em dezessete categorias (coluna 1 do Quadro 2 ).

Destacamos, também, que em relação à subcategoria de ação discente 'Observam o parceiro de dupla e os outros alunos realizarem a atividade do OA' da categoria 'Observa' poderia representar uma atitude passiva dos discentes. Apesar disso, não a consideramos como um comportamento passivo visto que sempre ocorreram ações posteriores de auxílio aos parceiros de dupla e aos outros alunos no decurso da realização da atividade do OA.

Ressaltamos que apesar da proposta do professor ter sido o uso da LD para a exploração do OA, algumas duplas de alunos, por iniciativa própria, preferiram realizar as atividades utilizando o ultrabook, equipamento necessário para o funcionamento da LD portátil utilizada pelos pesquisadores; razão pela qual foram subcategorizadas ações discentes 
relacionadas ao uso desse equipamento tecnológico que também permitiu explorar o OA com todas suas potencialidades.

Ainda, quanto às ações discentes de desenhar e realizar cálculos no quadro negro ressaltamos que esses registros feitos pelos alunos sempre os auxiliaram nas tentativas de busca por uma solução das tarefas da atividade do OA, facilitando e agilizando o processo de obtenção do resultado de um cálculo envolvendo, principalmente, a operação de divisão de números racionais. Tais ações ocorreram a partir do momento em que surgiram atividades envolvendo o conteúdo de áreas fracionárias, devido ao fato de os alunos apresentarem maior dificuldade na realização da mesma.

Quanto à subcategoria da categoria de ação docente 'Calibra' e sua única subcategoria 'Calibra a LD' estão relacionadas ao procedimento técnico de calibração da $\mathrm{LD}$ - procedimento indispensável para o bom funcionamento da caneta digital - realizado pelo professor. Essa única subcategoria de ação docente, não despertou a curiosidade dos alunos. Em razão disso, não fizeram questionamentos a respeito dos procedimentos de calibração da LD, tendo unicamente a atitude passiva de 'esperar', revelada pela subcategoria de ação discente 'Esperam o professor calibrar a LD' acomodada na categoria 'Espera'.

No Quadro 3 exibimos os dados organizados a respeito da categoria de ação docente 'Comenta' e suas cinco subcategorias: 'Comenta com os alunos como eles serão avaliados através da realização da atividade do OA', 'Comenta com os alunos que as tarefas da atividade do OA serão realizadas em duplas', 'Comenta com os alunos que auxiliará as duplas na realização da atividade do OA', 'Comenta com os alunos que eles podem auxiliar e solicitar auxílio aos outros alunos e ao professor' e 'Comenta que cada dupla realizará seis tarefas da atividade do OA'; que representam comentários distintos aos alunos.

Quadro 3 - Categoria e subcategorias de ações discentes relativas à categoria 'Comenta'

\begin{tabular}{|l|l||}
\hline \hline Categoria de ação discente & \multicolumn{1}{c|}{ Subcategorias de ações discentes } \\
\hline \hline Escuta & Escutam o professor comentar que as tarefas da atividade do OA serão realizadas em \\
& duplas. \\
& Escutam o professor comentar que auxiliará as duplas na realização da atividade do \\
& OA. \\
& Escutam o professor comentar que cada dupla realizará seis tarefas da atividade do \\
& OA. \\
& Escutam o professor comentar que eles podem auxiliar e solicitar auxílio aos outros \\
& alunos e a ele. \\
& Escutam o professor comentar sobre a maneira como serão avaliados através da \\
& realização da atividade do OA. \\
\hline
\end{tabular}

Fonte: Autores.

Observando atentamente as ações realizadas pelos discentes registradas (coluna 2 do Quadro 3), constatamos que esse foi um dos momentos no qual os discentes praticaram uma única ação, a de escutarem todos os comentários realizados pelo docente, não surgindo outra categoria sem ser a ação de 'escutar', muito comum em aulas expositivas e que também se faz presente em aulas fundamentadas no uso de tecnologias, ficando evidenciado uma semelhança entre esses diferentes tipos de abordagens metodológicas.

Referente à categoria de ação docente 'Coordena', houve uma única subcategoria: 'Coordena as duplas durante a exploração do OA', que não produziu categorias e subcategorias de ações discentes. E ressaltamos que em todo o nosso processo analítico, essa foi a única ação docente que não percebemos ter suscitado ações nos discentes.

O Quadro 4 traz informações a respeito das categorias e subcategorias de ações discentes, referentes à categoria de ação docente 'Demonstra' e suas três subcategorias: 'Demonstra aos alunos como arrastar objetos com a caneta digital no modo 'interativo", 'Demonstra aos alunos como arrastar objetos com o mouse do ultrabook' e 'Demonstra aos alunos como realizar a atividade do OA'. 
Quadro 4 - Categoria e subcategorias de ações discentes relativas à categoria 'Demonstra'.

\begin{tabular}{||c||l||}
\hline Categoria de ação discente & \multicolumn{1}{|c|}{ Subcategorias de ações discentes } \\
\hline \hline Presta atenção & Prestam atenção no professor ao demonstrar como arrastar objetos com a caneta digital \\
& no modo 'interativo'. \\
& $\begin{array}{l}\text { Prestam atenção no professor ao demonstrar como arrastar objetos com o mouse do } \\
\text { ultrabook. } \\
\\
\text { Prestam atenção no professor ao demonstrar como realizar a atividade do OA. }\end{array}$ \\
\hline \hline
\end{tabular}

Fonte: Autores.

Ao que concerne à categoria de ação docente 'Demonstra', ressaltamos que não houve a necessidade de o professor realizar a demonstração da maneira de calibrar a LD e utilizar a caneta digital, uma vez que os alunos investigados conheciam esses recursos tecnológicos por já terem utilizado, em outros momentos, nas aulas de Matemática.

Quanto às subcategorias (coluna 2 do Quadro 4) da categoria de ação discente 'Presta atenção', as mesmas evidenciaram que os alunos unicamente praticaram a ação de 'prestar atenção' no professor, enquanto ele fazia as demonstrações da maneira como arrastar objetos por meio da utilização da caneta digital e do mouse do ultrabook, bem como, realizar a atividade do OA por meio da execução de algumas tarefas de cada um dos níveis de dificuldade - de 1 (nível de menor dificuldade) a 6 (nível de maior dificuldade) - proporcionados pelo recurso explorado, os quais o usuário poderá vir a selecionar. Informamos, ainda, que não houve questionamentos por parte dos discentes quanto aos procedimentos de 'demonstração' realizados pelo docente. Segundo nossas percepções, tal fato deu-se em razão desses alunos terem conhecimento técnico suficiente para arrastar objetos com a caneta digital e (ou) o mouse do ultrabook, por já terem explorados $\mathrm{OA}$ em aulas de Matemática, anteriormente à realização desta investigação.

No prosseguimento, apresentamos, no Quadro 5, os resultados referentes à categoria de ação docente 'Discute' e suas duas subcategorias: 'Discute com os alunos possíveis estratégias de resolução para a atividade do OA' e 'Discute com os alunos possíveis soluções para a atividade do OA'.

Quadro 5 - Categoria e subcategorias de ações discentes relativas à categoria 'Discute'

\begin{tabular}{||l|l||}
\hline Categoria de ação discente & \multicolumn{1}{|c|}{ Subcategorias de ações discentes } \\
\hline \hline Discute & Discutem possíveis estratégias de resolução para a atividade do OA com o parceiro de \\
& dupla e os outros alunos. \\
& Discutem possíveis estratégias de resolução para a atividade do OA com o professor. \\
& Discutem possíveis soluções para a atividade do OA com o parceiro de dupla e os \\
& outros alunos. \\
& Discutem possíveis soluções para a atividade do OA com o professor. \\
\hline
\end{tabular}

Fonte: Autores.

As subcategorias de ações do professor, exibidas no parágrafo que antecede o Quadro 5, consistiram em ações que mobilizaram os alunos a, também, discutirem possíveis soluções e estratégias de resolução para a realização das tarefas da atividade do OA explorado, não somente com o professor e alunos de outras equipes, mas principalmente com os parceiros de dupla; evidenciando momentos importantes de aprendizagem, em virtude da metodologia utilizada pelo docente ter propiciado, para esse grupo de alunos, a construção coletiva do conhecimento matemático, proposições primárias dos processos de ensinar e de aprender.

Retomando as subcategorias de ações discentes (coluna 2 do Quadro 5) percebemos uma participação ativa dos alunos favorecida pelo uso das tecnologias em sala de aula. Ainda, tais ações, mostraram que o uso das tecnologias modificou as relações: alunos-alunos; alunos-professor e alunos-conhecimento; propiciando novas maneiras de aprendizagem. Segundo as concepções de Rocha e Rodrigues (2005, p. 23) "as aprendizagens da matemática em ambientes informatizados apresentam recursos em consonância com processo de aprendizagem construtivista, o qual tem como princípio básico que o conhecimento 
se constrói a partir das ações do sujeito".

Na continuidade, exibimos no Quadro 6 os resultados relativos à categoria de ação docente 'Espera' e de suas quatro subcategorias: 'Espera ocorrer a conexão entre os equipamentos (projetor, receptor da LD e ultrabook)', 'Espera os alunos realizarem a atividade do OA', 'Espera os alunos responderem aos seus questionamentos sobre a atividade do OA' e 'Espera os alunos responderem aos seus questionamentos sobre os conteúdos do OA'.

Quadro 6 - Categorias e subcategorias de ações discentes relativas à categoria 'Espera'.

\begin{tabular}{|l|l||}
\hline \multicolumn{1}{|c|}{ Categorias de ações discentes } & \multicolumn{1}{|c|}{ Subcategorias de ações discentes } \\
\hline \hline Apaga & Apagam os registros do quadro negro. \\
\hline \hline Arrasta & $\begin{array}{l}\text { Arrastam objetos com a caneta digital no modo 'interativo'. } \\
\text { Arrastam objetos com o mouse do ultrabook. }\end{array}$ \\
\hline \hline Arrisca & Arriscam uma resposta para a atividade do OA. \\
\hline \hline Auxilia & $\begin{array}{l}\text { Auxiliam o parceiro de dupla e os outros alunos na atividade do OA. } \\
\text { Auxiliam o parceiro de dupla e os outros alunos nos conteúdos do OA. }\end{array}$ \\
\hline \hline Comemora & Comemoram os acertos. \\
\hline \hline Desenha & $\begin{array}{l}\text { Conferem a resposta da atividade do OA com a caneta digital no modo 'interativo'. } \\
\text { Conferem a resposta da atividade do OA com o mouse do ultrabook. }\end{array}$ \\
\hline \hline Inicia & Desenham no quadro negro. \\
\hline \hline Espera & Iniciam a atividade do OA. \\
\hline \hline Observa & $\begin{array}{l}\text { Esperam ocorrer a conexão entre os equipamentos (projetor, receptor da LD e } \\
\text { ultrabook). }\end{array}$ \\
\hline \hline Presta atenção & Observam o parceiro de dupla e os outros alunos realizarem a atividade do OA. \\
\hline \hline Realiza & $\begin{array}{l}\text { Prestam atenção na atividade do OA através da área de projeção da LD. } \\
\text { Prestam atenção na atividade do OA através da tela do ultrabook. }\end{array}$ \\
\hline \hline Responde & $\begin{array}{l}\text { Realizam a atividade do OA com a caneta digital no modo 'interativo'. } \\
\text { Realizam a atividade do OA com o mouse do } \text { ultrabook. } \\
\text { Realizam cálculos no quadro negro. }\end{array}$ \\
\hline \hline Seleciona & $\begin{array}{l}\text { Respondem aos questionamentos do professor sobre a atividade do OA. } \\
\text { Respondem aos questionamentos do professor sobre os conteúdos do OA. }\end{array}$ \\
\hline \hline & $\begin{array}{l}\text { Selecionam a atividade do OA com a caneta digital no modo 'interativo'. } \\
\text { Selecionam a atividade do OA com o mouse do } \text { ultrabook. } \\
\text { Selecionam a resposta da atividade do OA com a caneta digital no modo 'interativo'. } \\
\text { Selecionam a resposta da atividade do OA com o mouse do ultrabook. } \\
\text { Selecionam o nível de dificuldade da atividade do OA com a caneta digital no modo } \\
\text { 'interativo'. } \\
\text { Selecionam o nível de dificuldade da atividade do OA com o mouse do } \text { ultrabook. }\end{array}$ \\
\hline Utilizam diferentes estratégias de resolução para a atividade do OA. \\
\hline
\end{tabular}

Fonte: Autores.

As ações do professor, representadas por quatro subcategorias da categoria de ação docente 'Espera', apresentadas no parágrafo que antecede o Quadro 6, conduziram os discentes a praticarem a ação de esperar ocorrer a conexão entre esses equipamentos, mas sem deixar de levar os alunos a desenvolverem diversas ações, como podemos observar retomando os dados alocados na coluna 2 do Quadro 6.

O Quadro 7, acomoda os registros interpretativos resultantes das ações discentes decorrentes da categoria de ação docente 'Explica' e de suas sete subcategorias: 'Explica aos alunos como arrastar os objetos com a caneta digital no modo 'interativo", 'Explica aos alunos como arrastar os objetos com o mouse do ultrabook', 'Explica aos alunos que cada dupla realizará seis tarefas da atividade do OA', 'Explica aos alunos sobre a atividade do OA', 'Explica aos alunos sobre a existência de diferentes níveis de dificuldade para a atividade do OA', 'Explica aos alunos sobre os conteúdos da atividade do OA' e 'Explica aos alunos técnicas de cálculo mental'. 
Quadro 7 - Categorias e subcategorias de ações discentes relativas à categoria 'Explica'.

\begin{tabular}{|c|c|}
\hline Categorias de ações discentes & "Subcategorias de ações discentes \\
\hline Apaga & Apagam os registros do quadro negro. \\
\hline Arrasta & $\begin{array}{l}\text { Arrastam objetos com a caneta digital no modo 'interativo'. } \\
\text { Arrastam objetos com o mouse do ultrabook. }\end{array}$ \\
\hline Arrisca & Arriscam uma resposta para a atividade do OA. \\
\hline Auxilia & $\begin{array}{l}\text { Auxiliam o parceiro de dupla e os outros alunos na atividade do OA. } \\
\text { Auxiliam o parceiro de dupla e os outros alunos nos conteúdos do OA. }\end{array}$ \\
\hline Comemora & Comemoram os acertos. \\
\hline Confere & $\begin{array}{l}\text { Conferem a resposta da atividade do OA com a caneta digital no modo 'interativo'. } \\
\text { Conferem a resposta da atividade do OA com o mouse do ultrabook. }\end{array}$ \\
\hline Desenha & Desenham no quadro negro. \\
\hline Incentiva & $\begin{array}{l}\text { Incentivam o parceiro de dupla e os outros alunos a buscarem diferentes estratégias de } \\
\text { resolução para a atividade do OA. } \\
\text { Incentivam o parceiro de dupla e os outros alunos a realizarem a atividade do OA. }\end{array}$ \\
\hline Indica & $\begin{array}{l}\text { Indicam o erro cometido ao parceiro de dupla e aos outros alunos durante a realização } \\
\text { da atividade do OA. }\end{array}$ \\
\hline Inicia & Iniciam a atividade do OA. \\
\hline Observa & Observam o parceiro de dupla e os outros alunos realizarem a atividade do OA. \\
\hline Pergunta & $\begin{array}{l}\text { Perguntam ao parceiro de dupla e aos outros alunos sobre a atividade do OA. } \\
\text { Perguntam ao parceiro de dupla e aos outros alunos sobre os conteúdos do OA. } \\
\text { Perguntam ao professor se podem realizar cálculos no quadro negro. } \\
\text { Perguntam ao professor sobre a atividade do OA. } \\
\text { Perguntam ao professor sobre a quantidade de tarefas da atividade do OA cada dupla } \\
\text { terá que realizar. } \\
\text { Perguntam ao professor sobre os conteúdos do OA. }\end{array}$ \\
\hline Presta atenção & $\begin{array}{l}\text { Prestam atenção na atividade do OA através da área de projeção da LD. } \\
\text { Prestam atenção na atividade do OA através da tela do ultrabook. } \\
\text { Prestam atenção na explicação do professor sobre a atividade do OA. } \\
\text { Prestam atenção na explicação do professor sobre a existência de diferentes níveis de } \\
\text { dificuldade para a atividade do OA. } \\
\text { Prestam atenção na explicação do professor sobre a forma de arrastar objetos com a } \\
\text { caneta digital no modo 'interativo'. } \\
\text { Prestam atenção na explicação do professor sobre a quantidade de tarefas que cada } \\
\text { dupla realizará da atividade do OA. } \\
\text { Prestam atenção na explicação do professor sobre os conteúdos do OA. } \\
\text { Prestam atenção na explicação do professor sobre técnicas de cálculo mental. }\end{array}$ \\
\hline Realiza & $\begin{array}{l}\text { Realizam a atividade do OA com a caneta digital no modo 'interativo'. } \\
\text { Realizam a atividade do OA com o mouse do ultrabook. } \\
\text { Realizam cálculos mentalmente. } \\
\text { Realizam cálculos no quadro negro. }\end{array}$ \\
\hline Responde & $\begin{array}{l}\text { Respondem aos questionamentos do parceiro de dupla e dos outros alunos sobre a } \\
\text { atividade do OA. } \\
\text { Respondem aos questionamentos do parceiro de dupla e dos outros alunos sobre os } \\
\text { conteúdos do OA. } \\
\text { Respondem aos questionamentos do professor sobre a atividade do OA. } \\
\text { Respondem aos questionamentos do professor sobre os conteúdos do OA. }\end{array}$ \\
\hline Seleciona & $\begin{array}{l}\text { Selecionam a atividade do OA com a caneta digital no modo 'interativo'. } \\
\text { Selecionam a atividade do OA com o mouse do ultrabook. } \\
\text { Selecionam a resposta da atividade do OA com a caneta digital no modo 'interativo'. } \\
\text { Selecionam a resposta da atividade do OA com o mouse do ultrabook. } \\
\text { Selecionam o nível de dificuldade da atividade do OA com a caneta digital no modo } \\
\text { 'interativo'. } \\
\text { Selecionam o nível de dificuldade da atividade do OA com o mouse do ultrabook. }\end{array}$ \\
\hline Solicita auxílio & $\begin{array}{l}\text { Solicitam auxílio ao parceiro de dupla e aos outros alunos sobre a atividade do OA. } \\
\text { Solicitam auxílio ao parceiro de dupla e aos outros alunos sobre os conteúdos do OA. }\end{array}$ \\
\hline Solicita explicação & $\begin{array}{l}\text { Solicitam explicação ao professor sobre a atividade do OA. } \\
\text { Solicitam explicação ao professor sobre os conteúdos do OA. }\end{array}$ \\
\hline Utiliza & Utilizam diferentes estratégias de resolução para a atividade do OA. \\
\hline
\end{tabular}

Fonte: Autores.

As subcategorias acomodadas na categoria de ação docente 'Explica', apresentadas anteriormente à exposição do 
Quadro 7, mobilizaram os alunos a irem além da simples ação de 'prestar atenção' nas explicações do professor e podem ser revistas, para conferência, no Quadro 7 (coluna 2), as quarenta e oito subcategorias distintas de ações discentes.

Ainda, concernente à subcategoria 'Explica aos alunos sobre os conteúdos da atividade do OA', ressaltamos que o professor retomou os conceitos de área e perímetro ${ }^{6}$ de figuras geométricas planas já estudados pelos discentes durante o ano letivo no qual ocorreu esta investigação. Também utilizou duas tarefas da atividade do OA para a exemplificação desses conceitos por meio de um recurso lúdico, com o intuito de promover mudanças nas formas de ensinar e de aprender esses conhecimentos.

Dessa forma, no que se refere às formas de exposição e de acordo com o que observamos em relação à ação docente em sala de aula, o professor utilizou a exposição verbal, a exemplificação, a demonstração e a ilustração; formas que de acordo com as concepções de Libâneo (1994), em geral, podem ser conjugadas propiciando o enriquecimento de aulas expositivas.

A seguir, trazemos duas frases representativas do professor referentes à subcategoria de ação docente 'Explica aos alunos sobre a atividade do OA': "Vocês terão que descobrir a área da figura formada" e "O objeto de aprendizagem deu a solução. Não tem uma nova chance".

Por último, ressaltamos que a partir do momento em que uma das duplas perguntou ao professor se poderiam realizar cálculos, necessários para a resolução da atividade do OA, no quadro negro; muitos alunos passaram a fazer uso desse recurso, indicando-nos que a utilização de uma estratégia bem-sucedida por alguns alunos, estimula outros a empregarem esse método.

Na continuidade trazemos, no Quadro 8, as categorias e subcategorias de ações discentes resultantes da categoria de ação docente 'Expõe', que está acompanhada de uma única subcategoria: 'Expõe aos alunos quais conteúdos serão estudados através da realização da atividade do OA'.

Quadro 8 - Categorias e subcategorias de ações discentes relativas à categoria 'Expõe'.

\begin{tabular}{||l|l||}
\hline \hline Categorias de ações discentes & \multicolumn{1}{c|}{ Subcategorias de ações discentes } \\
\hline \hline Escuta & $\begin{array}{l}\text { Escutam o professor expor sobre os conteúdos a serem estudados através da realização } \\
\text { da atividade do OA. }\end{array}$ \\
\hline \hline Pergunta & $\begin{array}{l}\text { Perguntam ao professor quais conteúdos serão estudados através da realização da } \\
\text { atividade do OA. }\end{array}$ \\
\hline
\end{tabular}

Fonte: Autores.

Como pode ser retomado no Quadro 8, a exposição do professor acerca dos conteúdos a serem estudados por meio da realização da atividade do OA desencadeou duas ações - subcategorias de ações discentes - por parte dos alunos (coluna 2) alojadas nas categorias de ações discentes 'Escuta' e 'Pergunta'. A frase - “O que vamos estudar hoje?” - emitida por um dos alunos, ao referir-se aos conteúdos que seriam estudados na aula, clarifica o surgimento da subcategoria de ação discente (coluna 2 do Quadro 8) acomodada na categoria 'Pergunta' (coluna 1 do Quadro 8) e revela o interesse e (ou) a curiosidade do discente pelo conteúdo matemático.

No Quadro 9, exibimos as categorias e subcategorias de ações discentes decorrentes da ação docente 'Incentiva' e de suas três subcategorias: 'Incentiva os alunos a auxiliarem o parceiro de dupla e os outros alunos na realização da atividade do OA', 'Incentiva os alunos a buscarem diferentes estratégias de resolução para a atividade do OA' e 'Incentiva os alunos a realizarem a atividade do $\mathrm{OA}^{\prime}$.

\footnotetext{
${ }^{6}$ O perímetro definido como: a medida do contorno de qualquer figura plana e a soma das medidas dos lados de um polígono; enquanto área foi conceituada como: a medida de uma superfície; a área da superfície limitada por um polígono (Bianchini, 2015); apresentados pelo docente como conceitos distintos.
} 
Quadro 9 - Categorias e subcategorias de ações discentes relativas à categoria 'Incentiva' .

\begin{tabular}{|c|c|}
\hline Categorias de ações discentes & Subcategorias de ações discentes \\
\hline Apaga & Apagam os registros do quadro negro. \\
\hline Arrasta & $\begin{array}{l}\text { Arrastam objetos com a caneta digital no modo 'interativo'. } \\
\text { Arrastam objetos com o mouse do ultrabook. }\end{array}$ \\
\hline Arrisca & Arriscam uma resposta para a atividade do OA. \\
\hline Auxilia & $\begin{array}{l}\text { Auxiliam o parceiro de dupla e os outros alunos na atividade do OA. } \\
\text { Auxiliam o parceiro de dupla e os outros alunos nos conteúdos do OA. }\end{array}$ \\
\hline Comemora & Comemoram os acertos. \\
\hline Confere & $\begin{array}{l}\text { Conferem a resposta da atividade do OA com a caneta digital no modo 'interativo'. } \\
\text { Conferem a resposta da atividade do OA com o mouse do ultrabook. }\end{array}$ \\
\hline Desenha & Desenham no quadro negro. \\
\hline Incentiva & $\begin{array}{l}\text { Incentivam o parceiro de dupla e os outros alunos a buscarem diferentes estratégias de } \\
\text { resolução para a atividade do OA. } \\
\text { Incentivam o parceiro de dupla e os outros alunos a realizarem a atividade do OA. }\end{array}$ \\
\hline Inicia & Iniciam a atividade do OA. \\
\hline Observa & Observam o parceiro de dupla e os outros alunos realizarem a atividade do OA. \\
\hline Presta atenção & $\begin{array}{l}\text { Prestam atenção na atividade do OA através da área de projeção da LD. } \\
\text { Prestam atenção na atividade do OA através da tela do ultrabook. }\end{array}$ \\
\hline Realiza & $\begin{array}{l}\text { Realizam a atividade do OA com a caneta digital no modo 'interativo'. } \\
\text { Realizam a atividade do OA com o mouse do ultrabook. } \\
\text { Realizam cálculos mentalmente. } \\
\text { Realizam cálculos no quadro negro. }\end{array}$ \\
\hline Seleciona & $\begin{array}{l}\text { Selecionam a atividade do OA com a caneta digital no modo 'interativo'. } \\
\text { Selecionam a atividade do OA com o mouse do ultrabook. } \\
\text { Selecionam a resposta da atividade do OA com a caneta digital no modo 'interativo'. } \\
\text { Selecionam a resposta da atividade do OA com o mouse do ultrabook. } \\
\text { Selecionam o nível de dificuldade da atividade do OA com a caneta digital no modo } \\
\text { 'interativo'. } \\
\text { Selecionam o nível de dificuldade da atividade do OA com o mouse do ultrabook. }\end{array}$ \\
\hline Solicita auxílio & $\begin{array}{l}\text { Solicitam auxílio ao parceiro de dupla e aos outros alunos sobre a atividade do OA. } \\
\text { Solicitam auxílio ao parceiro de dupla e aos outros alunos sobre os conteúdos do OA. }\end{array}$ \\
\hline Utiliza & Utilizam diferentes estratégias de resolução para a atividade do OA. \\
\hline
\end{tabular}

Fonte: Autores.

As subcategorias referentes à categoria de ação docente 'Incentiva', exibidas no parágrafo que antecede ao Quadro 9, evidenciaram que houve uma mobilização dos alunos para a realização de diversas ações, como é possível verificar por meio da observação das subcategorias de ações discentes alocadas na coluna 2 do Quadro 9.

O comentário do professor "Vamos lá! Quem está aí pode ajudar a dupla que está fazendo a atividade" retrata um dos momentos em que o docente incentivou os alunos a auxiliarem seus colegas.

A seguir, no Quadro 10, temos os dados interpretados a respeito das categorias e subcategorias de ações discentes suscitadas da categoria de ação docente 'Indica' e de suas duas subcategorias: 'Indica o erro cometido pela dupla durante a realização da atividade do OA' e 'Indica possíveis estratégias de resolução para a atividade do OA'. 
Quadro 10 - Categorias e subcategorias de ações discentes relativas à categoria 'Indica'.

\begin{tabular}{|c|c|}
\hline Categorias de ações discentes & Subcategorias de ações discentes \\
\hline Aceita ou não & Aceitam ou não as estratégias do professor para a resolução da atividade do OA. \\
\hline Apaga & Apagam os registros do quadro negro. \\
\hline Arrasta & $\begin{array}{l}\text { Arrastam objetos com a caneta digital no modo 'interativo'. } \\
\text { Arrastam objetos com o mouse do ultrabook. }\end{array}$ \\
\hline Arrisca & Arriscam uma resposta para a atividade do OA. \\
\hline Auxilia & $\begin{array}{l}\text { Auxiliam o parceiro de dupla e os outros alunos na atividade do OA. } \\
\text { Auxiliam o parceiro de dupla e os outros alunos nos conteúdos do OA. }\end{array}$ \\
\hline Comemora & Comemoram os acertos. \\
\hline Confere & $\begin{array}{l}\text { Conferem a resposta da atividade do OA com a caneta digital no modo 'interativo'. } \\
\text { Conferem a resposta da atividade do OA com o mouse do ultrabook. }\end{array}$ \\
\hline Desenha & Desenham no quadro negro. \\
\hline Incentiva & $\begin{array}{l}\text { Incentivam o parceiro de dupla e os outros alunos a buscarem diferentes estratégias de } \\
\text { resolução para a atividade do OA. } \\
\text { Incentivam o parceiro de dupla e os outros alunos a realizarem a atividade do OA. }\end{array}$ \\
\hline Indica & $\begin{array}{l}\text { Indicam o erro cometido ao parceiro de dupla e aos outros alunos durante a realização } \\
\text { da atividade do OA. }\end{array}$ \\
\hline Inicia & Iniciam a atividade do OA. \\
\hline Observa & Observam o parceiro de dupla e os outros alunos realizarem a atividade do OA. \\
\hline Presta atenção & $\begin{array}{l}\text { Prestam atenção na atividade do OA através da área de projeção da LD. } \\
\text { Prestam atenção na atividade do OA através da tela do ultrabook. }\end{array}$ \\
\hline Realiza & $\begin{array}{l}\text { Realizam a atividade do OA com a caneta digital no modo 'interativo'. } \\
\text { Realizam a atividade do OA com o mouse do ultrabook. } \\
\text { Realizam cálculos mentalmente. } \\
\text { Realizam cálculos no quadro negro. }\end{array}$ \\
\hline Seleciona & $\begin{array}{l}\text { Selecionam a atividade do OA com a caneta digital no modo 'interativo'. } \\
\text { Selecionam a atividade do OA com o mouse do ultrabook. } \\
\text { Selecionam a resposta da atividade do OA com a caneta digital no modo 'interativo'. } \\
\text { Selecionam a resposta da atividade do OA com o mouse do ultrabook. } \\
\text { Selecionam o nível de dificuldade da atividade do OA com a caneta digital no modo } \\
\text { 'interativo'. } \\
\text { Selecionam o nível de dificuldade da atividade do OA com o mouse do ultrabook. }\end{array}$ \\
\hline Utiliza & "Utilizam diferentes estratégias de resolução para a atividade do OA. \\
\hline
\end{tabular}

Fonte: Autores.

As ações realizadas pelo docente apresentadas no parágrafo que antecede o quadro anterior, bem como as ações dos discentes (coluna 2 do Quadro 10) evidenciaram que os alunos passaram a indicar o erro cometido pelos outros alunos durante a realização da atividade do OA, após essa indicação ter sido realizada, primeiramente, pelo professor.

Tendo em consideração a próxima categoria de ação docente que denominamos por 'Liga', existiu uma única subcategoria: 'Liga os equipamentos (projetor, receptor da LD e ultrabook)'; originando uma única subcategoria de ação discente 'Esperam o professor ligar os equipamentos (projetor, receptor da LD e ultrabook)' acomodada na categoria de ação discente 'Espera', melhor dizendo, no momento em que o professor pratica a ação de ligar os equipamentos, os alunos unicamente esperam o professor realizar tal procedimento.

Quanto ao Quadro 11, nele expomos os resultados referentes às ações discentes decorrente da categoria de ação docente 'Pergunta', que tem como subcategorias o seguinte elenco: 'Pergunta aos alunos qual dupla dará início à exploração do OA na LD', 'Pergunta aos alunos sobre a atividade do OA', 'Pergunta aos alunos sobre a solução da atividade do OA' e 'Pergunta aos alunos sobre os conteúdos do OA'. 
Quadro 11 - Categorias e subcategorias de ações discentes relativas à categoria 'Pergunta'.

\begin{tabular}{|c|c|}
\hline Categorias de ações discentes & Subcategorias de ações discentes \\
\hline Apaga & Apagam os registros do quadro negro. \\
\hline Arrasta & $\begin{array}{l}\text { Arrastam objetos com a caneta digital no modo 'interativo'. } \\
\text { Arrastam objetos com o mouse do ultrabook. }\end{array}$ \\
\hline Arrisca & Arriscam uma resposta para a atividade do OA. \\
\hline Auxilia & $\begin{array}{l}\text { Auxiliam o parceiro de dupla e os outros alunos na atividade do OA. } \\
\text { Auxiliam o parceiro de dupla e os outros alunos na busca por estratégias de resolução } \\
\text { da atividade do OA. } \\
\text { Auxiliam o parceiro de dupla e os outros alunos nos conteúdos do OA. }\end{array}$ \\
\hline Comemora & Comemoram os acertos. \\
\hline Confere & $\begin{array}{l}\text { Conferem a resposta da atividade do OA com a caneta digital no modo 'interativo'. } \\
\text { Conferem a resposta da atividade do OA com o mouse do ultrabook. }\end{array}$ \\
\hline Desenha & Desenham no quadro negro. \\
\hline Discute & $\begin{array}{l}\text { Discutem possíveis estratégias de resolução para a atividade do OA com o parceiro de } \\
\text { dupla e os outros alunos. } \\
\text { Discutem possíveis soluções para a atividade do OA com o parceiro de dupla e os } \\
\text { outros alunos. } \\
\text { Discutem possíveis soluções para a atividade do OA com o professor. }\end{array}$ \\
\hline Fala & $\begin{array}{l}\text { Falam a resposta da atividade do OA ao parceiro de dupla e aos outros alunos. } \\
\text { Falam ao parceiro de dupla que a sua estratégia de resolução da atividade do OA está } \\
\text { correta. }\end{array}$ \\
\hline Incentiva & $\begin{array}{l}\text { Incentivam o parceiro de dupla e os outros alunos a buscarem diferentes estratégias de } \\
\text { resolução para a atividade do OA. } \\
\text { Incentivam o parceiro de dupla e os outros alunos a realizarem a atividade do OA. }\end{array}$ \\
\hline Indica & $\begin{array}{l}\text { Indicam o erro cometido ao parceiro de dupla e aos outros alunos durante a realização } \\
\text { da atividade do OA. }\end{array}$ \\
\hline Inicia & Iniciam a atividade do OA. \\
\hline Justifica & Justificam ao professor a resposta dada. \\
\hline Observa & Observam o parceiro de dupla e os outros alunos realizarem a atividade do OA. \\
\hline Presta atenção & $\begin{array}{l}\text { Prestam atenção na atividade do OA através da área de projeção da LD. } \\
\text { Prestam atenção na atividade do OA através da tela do ultrabook. }\end{array}$ \\
\hline Realiza & $\begin{array}{l}\text { Realizam a atividade do OA com a caneta digital no modo 'interativo'. } \\
\text { Realizam a atividade do OA com o mouse do ultrabook. } \\
\text { Realizam cálculos mentalmente. } \\
\text { Realizam cálculos no quadro negro. }\end{array}$ \\
\hline Responde & $\begin{array}{l}\text { Respondem aos questionamentos dos outros alunos sobre a atividade do OA. } \\
\text { Respondem aos questionamentos dos outros alunos sobre os conteúdos do OA. } \\
\text { Respondem às perguntas do professor sobre a atividade do OA. } \\
\text { Respondem às perguntas do professor sobre a solução da atividade do OA. } \\
\text { Respondem às perguntas do professor sobre os conteúdos do OA. }\end{array}$ \\
\hline Seleciona & $\begin{array}{l}\text { Selecionam a atividade do OA com a caneta digital no modo 'interativo'. } \\
\text { Selecionam a atividade do OA com o mouse do ultrabook. } \\
\text { Selecionam a resposta da atividade do OA com a caneta digital no modo 'interativo'. } \\
\text { Selecionam a resposta da atividade do OA com o mouse do ultrabook. } \\
\text { Selecionam o nível de dificuldade da atividade do OA com a caneta digital no modo } \\
\text { 'interativo'. } \\
\text { Selecionam o nível de dificuldade da atividade do OA com o mouse do ultrabook. }\end{array}$ \\
\hline Solicita auxílio & $\begin{array}{l}\text { Solicitam auxílio ao parceiro de dupla e aos outros alunos sobre a atividade do OA. } \\
\text { Solicitam auxílio ao parceiro de dupla e aos outros alunos sobre os conteúdos do OA. }\end{array}$ \\
\hline Utiliza & Utilizam diferentes estratégias de resolução para a atividade do OA. \\
\hline
\end{tabular}

Fonte: Autores.

No quadro exposto anteriormente acomodamos os resultados referentes às ações discentes decorrentes da categoria de ação docente 'Pergunta', relacionada no parágrafo que antecede ao Quadro 11.

Quanto às ações docentes, relativas às ações de perguntar aos alunos sobre a atividade e os conteúdos do OA, seguem duas perguntas do professor que consideramos simbólicas a esse respeito: "Qual é o perímetro dessa figura?" e "Vocês entenderam a diferença entre área e perímetro?”

No prosseguimento, mostraremos um diálogo entre professor e aluno que estabelece a relação entre as ações docentes 
'Pergunta aos alunos sobre a atividade do OA' e 'Pergunta aos alunos sobre os conteúdos do OA'; e as ações discentes 'Respondem às perguntas do professor sobre a atividade do $\mathrm{OA}^{\prime}$ ' e 'Respondem às perguntas do professor sobre os conteúdos do OA'.

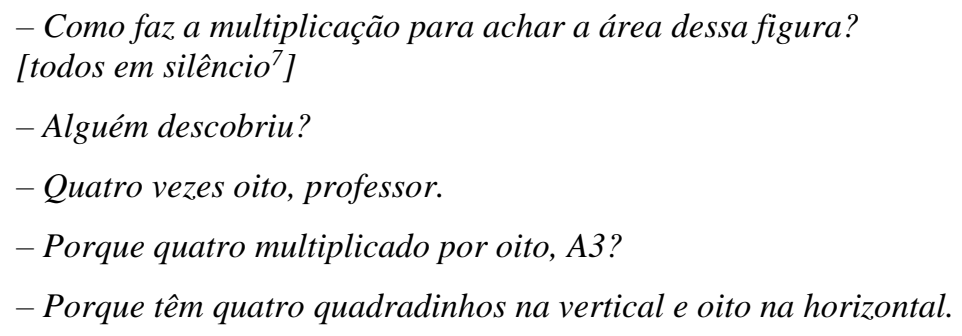

No que se refere às ações discentes, representadas por suas categorias e respectivas subcategorias, vinculadas à categoria de ação docente 'Presta atenção' e suas duas subcategorias: 'Presta atenção nas diferentes estratégias utilizadas pelos alunos na resolução da atividade do OA através da projeção da LD' e 'Presta atenção nos alunos enquanto eles realizam a atividade do OA através da projeção da LD'; são exibidas no Quadro 12.

\footnotetext{
${ }^{7}$ Após o questionamento do professor, todos os alunos permaneceram em silêncio absoluto por alguns segundos.
} 
Quadro 12 - Categorias e subcategorias de ações discentes relativas à categoria 'Presta atenção'.

\begin{tabular}{|c|c|}
\hline "Categorias de ações discentes & Subcategorias de ações discentes \\
\hline Apaga & Apagam os registros do quadro negro. \\
\hline Arrasta & $\begin{array}{l}\text { Arrastam objetos com a caneta digital no modo 'interativo'. } \\
\text { Arrastam objetos com o mouse do ultrabook. }\end{array}$ \\
\hline Arrisca & Arriscam uma resposta para a atividade do OA. \\
\hline Auxilia & $\begin{array}{l}\text { Auxiliam o parceiro de dupla e os outros alunos na atividade do OA. } \\
\text { Auxiliam o parceiro de dupla e os outros alunos nos conteúdos do OA. }\end{array}$ \\
\hline Comemora & Comemoram os acertos. \\
\hline Confere & $\begin{array}{l}\text { Conferem a resposta da atividade do OA com a caneta digital no modo 'interativo'. } \\
\text { Conferem a resposta da atividade do OA com o mouse do ultrabook. }\end{array}$ \\
\hline Desenha & Desenham no quadro negro. \\
\hline Discute & $\begin{array}{l}\text { Discutem diferentes estratégias de resolução para a atividade do OA com o parceiro de } \\
\text { dupla e os outros alunos. } \\
\text { Discutem possíveis soluções com o parceiro de dupla e os outros alunos. } \\
\text { Discutem possíveis soluções com o professor. }\end{array}$ \\
\hline Incentiva & $\begin{array}{l}\text { Incentivam o parceiro de dupla e os outros alunos a buscarem diferentes estratégias de } \\
\text { resolução para a atividade do OA. } \\
\text { Incentivam o parceiro de dupla e os outros alunos a realizarem a atividade do OA. }\end{array}$ \\
\hline Inicia & Iniciam a atividade do OA. \\
\hline Observa & Observam o parceiro de dupla e os outros alunos realizarem a atividade do OA. \\
\hline Presta atenção & $\begin{array}{l}\text { Prestam atenção na atividade do OA através da área de projeção da LD. } \\
\text { Prestam atenção na atividade do OA através da tela do ultrabook. }\end{array}$ \\
\hline Realiza & $\begin{array}{l}\text { Realizam a atividade do OA com a caneta digital no modo 'interativo'. } \\
\text { Realizam a atividade do OA com o mouse do ultrabook. } \\
\text { Realizam cálculos mentalmente. } \\
\text { Realizam cálculos no quadro negro. }\end{array}$ \\
\hline Seleciona & $\begin{array}{l}\text { Selecionam a atividade do OA com a caneta digital no modo 'interativo'. } \\
\text { Selecionam a atividade do OA com o mouse do ultrabook. } \\
\text { Selecionam a resposta da atividade do OA com a caneta digital no modo 'interativo'. } \\
\text { Selecionam a resposta da atividade do OA com o mouse do ultrabook. } \\
\text { Selecionam o nível de dificuldade da atividade do OA com a caneta digital no modo } \\
\text { 'interativo'. } \\
\text { Selecionam o nível de dificuldade da atividade do OA com o mouse do ultrabook. }\end{array}$ \\
\hline Utiliza & Utilizam diferentes estratégias de resolução para a atividade do OA. \\
\hline
\end{tabular}

Fonte: Autores.

As ações do professor acomodadas na categoria de ação docente 'Presta atenção', foram capazes de conduzir os alunos a desenvolverem trinta ações (coluna 2 do Quadro 12) distintas, acomodadas em quinze categorias de ações discentes (coluna 1 do Quadro 12) que evidenciam toda a dinâmica de desenvolvimento de autonomia dos alunos quanto à sua própria aprendizagem e do trabalho coletivo que ocorreu, principalmente, entre os alunos, oportunizado pelo uso das tecnologias digitais.

No Quadro 13 mostramos a categoria de ação discente e suas subcategorias, suscitadas da categoria de ação docente 'Projeta' e de sua única subcategoria: 'Projeta a atividade do OA através da LD'.

Quadro 13 - Categoria e subcategorias de ações discentes relativas à categoria 'Projeta'.

\begin{tabular}{||c||c||}
\hline \hline Categoria de ação discente & \multicolumn{1}{c|}{ Subcategorias de ações discentes } \\
\hline \hline Observa & $\begin{array}{l}\text { Observam a atividade do OA através da área de projeção da LD. } \\
\text { Observam a atividade do OA através da tela do ultrabook. }\end{array}$ \\
\hline
\end{tabular}

Fonte: Autores.

Apresentamos, no Quadro 13, uma categoria de ação discente e suas duas subcategorias, originadas da categoria de ação docente 'Projeta' e de sua subcategoria, evidenciando que os alunos unicamente praticaram a ação de 'observar', no momento em que o professor realizava a projeção do OA por meio da LD. 
Quanto à categoria de ação docente 'Realiza' e sua única subcategoria 'Realiza a chamada', observamos a ocorrência de uma única subcategoria de ação discente 'Respondem à chamada' alocada na categoria 'Responde'; melhor dizendo, os alunos apenas responderam à chamada. Enfatizamos que essa é uma prática habitual no ensino formal em consequência de ser uma prática burocrática obrigatória.

Apresentamos, no Quadro 14, os resultados referentes à análise da categoria de ação docente 'Resolve' e sua única subcategoria: 'Resolve problemas técnicos ocorridos com a conexão dos equipamentos (projetor, receptor da LD e ultrabook)'

Quadro 14 - Categoria e subcategorias de ações discentes relativas à categoria 'Resolve'.

\begin{tabular}{|l||l||}
\hline \hline Categoria de ação discente & \multicolumn{1}{|c|}{ Subcategorias de ações discentes } \\
\hline \hline Espera & $\begin{array}{l}\text { Esperam o professor resolver problemas técnicos ocorridos com a conexão dos } \\
\text { equipamentos (projetor, receptor da LD e ultrabook). }\end{array}$ \\
\hline
\end{tabular}

Fonte: Autores.

Em determinado momento da primeira aula analisada ocorreu um problema técnico com a conexão dos equipamentos (projetor, receptor da LD e ultrabook) que interrompeu a projeção do OA, bem como impediu o desenvolvimento da atividade que os alunos estavam realizando, tanto por meio da LD quanto através do ultrabook. Ressaltamos que o professor responsável pela implementação dessas aulas não conseguiu identificar as causas do problema. Porém, o docente solucionou o problema descrito desligando os equipamentos, ligando-os novamente e estabelecendo a conexão entre eles. Em razão desse acontecimento foi criada a subcategoria 'Resolve problemas técnicos ocorridos com a conexão dos equipamentos (projetor, receptor da LD e ultrabook)' acomodada na categoria de ação docente 'Resolve'. Por consequência, aos alunos coube a ação de 'esperar' o professor resolver o problema técnico ocorrido, gerando a subcategoria de ação discente 'Esperam o professor resolver problemas técnicos ocorridos com a conexão dos equipamentos (projetor, receptor da LD e ultrabook)’ alojada na categoria 'Espera'.

Exibimos, no Quadro 15, nossas considerações referentes às ações discentes suscitadas pela categoria de ação docente 'Responde' e suas duas subcategorias: 'Responde às perguntas dos alunos sobre a atividade do OA' e 'Responde às perguntas dos alunos sobre os conteúdos do OA'.

Quadro 15 - Categoria e subcategorias de ações discentes relativas à categoria 'Responde'.

\begin{tabular}{|c|l||}
\hline Categoria de ação discente & \multicolumn{1}{c|}{ Subcategorias de ações discentes } \\
\hline \hline Pergunta & $\begin{array}{l}\text { Perguntam ao professor sobre a atividade do OA. } \\
\text { Perguntam ao professor sobre os conteúdos do OA. }\end{array}$ \\
\hline
\end{tabular}

Fonte: Autores.

No Quadro 15, mostramos as ações discentes, alocadas na coluna 2, suscitadas pela categoria de ação docente 'Responde' e suas subcategorias. As subcategorias de ações discentes ocorreram devido ao surgimento de dúvidas dos alunos, no decorrer da realização da atividade, a respeito da própria atividade e dos conteúdos estudados com esse recurso.

$\mathrm{Na}$ continuidade, apresentamos um diálogo entre aluno e professor representativo da relação entre a ação discente 'Perguntam ao professor sobre a atividade do OA' e a ação docente 'Responde às perguntas dos alunos sobre a atividade do OA'.

\footnotetext{
- Quantas tarefas eles vão ter que fazer, professor?

- Cada equipe irá responder seis tarefas.
} 
Ainda, quanto à categoria de ação docente 'Responde', o professor praticou a ação de responder a pergunta proferida por um dos alunos sobre um assunto não relativo à atividade do $\mathrm{OA}$, não sendo, portanto, por nós categorizada e subcategorizada. No entanto, representou certo interesse do aluno que nos pareceu motivado pela metodologia utilizada pelo professor, logo, segue descrita resumidamente: o aluno A7 perguntou ao professor se era 'legal' ser professor de Matemática, tendo como resposta: "É muito gratificante ser professor de Matemática e poder ajudar os outros a aprender algo novo".

No Quadro 16 inserimos as categorias e subcategorias de ações discentes vinculadas à categoria de ação docente 'Solicita' que possui seis subcategorias: 'Solicita aos alunos para auxiliarem o parceiro de dupla e os outros alunos na atividade do OA', 'Solicita aos alunos para auxiliarem o parceiro de dupla e os outros alunos nos conteúdos do OA', 'Solicita aos alunos que façam silêncio', 'Solicita aos alunos que prestem atenção na atividade do OA', 'Solicita aos alunos que se organizem em duplas' e 'Solicita para que a dupla inicie a atividade do OA'.

Quadro 16 - Categorias e subcategorias de ações discentes relativas à categoria 'Solicita' .

\begin{tabular}{|c|c|}
\hline "Categorias de ações discentes & Pubcategorias de ações discentes \\
\hline Apaga & Apagam os registros do quadro negro. \\
\hline Arrasta & $\begin{array}{l}\text { Arrastam objetos com a caneta digital no modo 'interativo'. } \\
\text { Arrastam objetos com o mouse do ultrabook. }\end{array}$ \\
\hline Arrisca & Arriscam uma resposta para a atividade do OA. \\
\hline Auxilia & $\begin{array}{l}\text { Auxiliam o parceiro de dupla e os outros alunos na atividade do OA. } \\
\text { Auxiliam o parceiro de dupla e os outros alunos nos conteúdos do OA. }\end{array}$ \\
\hline Comemora & Comemoram os acertos. \\
\hline Confere & $\begin{array}{l}\text { Conferem a resposta da atividade do OA com a caneta digital no modo 'interativo'. } \\
\text { Conferem a resposta da atividade do OA com o mouse do ultrabook. }\end{array}$ \\
\hline Desenha & Desenham no quadro negro. \\
\hline Incentiva & $\begin{array}{l}\text { Incentivam o parceiro de dupla e os outros alunos a buscarem diferentes estratégias de } \\
\text { resolução para a atividade do OA. } \\
\text { Incentivam o parceiro de dupla e os outros alunos a realizarem a atividade do OA. }\end{array}$ \\
\hline Indica & $\begin{array}{l}\text { Indicam o erro cometido ao parceiro de dupla e aos outros alunos durante a realização } \\
\text { da atividade do OA. }\end{array}$ \\
\hline Inicia & Iniciam a atividade do OA. \\
\hline Observa & Observam o parceiro de dupla e os outros alunos realizarem a atividade do OA. \\
\hline Organiza & Organizam-se em duplas. \\
\hline Presta atenção & $\begin{array}{l}\text { Prestam atenção na atividade do OA através da área de projeção da LD. } \\
\text { Prestam atenção na atividade do OA através da tela do ultrabook. }\end{array}$ \\
\hline Realiza & $\begin{array}{l}\text { Realizam a atividade do OA com a caneta digital no modo 'interativo'. } \\
\text { Realizam a atividade do OA com o mouse do ultrabook. } \\
\text { Realizam cálculos mentalmente. } \\
\text { Realizam cálculos no quadro negro. }\end{array}$ \\
\hline Responde & $\begin{array}{l}\text { Respondem aos questionamentos dos outros alunos sobre a atividade do OA. } \\
\text { Respondem aos questionamentos dos outros alunos sobre os conteúdos do OA. }\end{array}$ \\
\hline Seleciona & $\begin{array}{l}\text { Selecionam a atividade do OA com a caneta digital no modo 'interativo'. } \\
\text { Selecionam a atividade do OA com o mouse do ultrabook. } \\
\text { Selecionam a resposta da atividade do OA com a caneta digital no modo 'interativo'. } \\
\text { Selecionam a resposta da atividade do OA com o mouse do ultrabook. } \\
\text { Selecionam o nível de dificuldade da atividade do OA com a caneta digital no modo } \\
\text { 'interativo'. } \\
\text { Selecionam o nível de dificuldade da atividade do OA com o mouse do ultrabook. }\end{array}$ \\
\hline Solicita auxílio & $\begin{array}{l}\text { Solicitam auxílio ao parceiro de dupla e aos outros alunos sobre a atividade do OA. } \\
\text { Solicitam auxílio ao parceiro de dupla e aos outros alunos sobre os conteúdos do OA. }\end{array}$ \\
\hline Utiliza & Utilizam diferentes estratégias de resolução para a atividade do OA. \\
\hline
\end{tabular}

Fonte: Autores.

As ações do professor descritas no parágrafo que antecede o Quadro 16 levaram os alunos a realizarem trinta e três ações distintas - subcategorias de ações discentes (coluna 2 do Quadro 16), revelando um movimento mais intenso de trabalho coletivo entre os alunos, fazendo uso de tecnologias digitais sob uma perspectiva colaborativa. 
No Quadro 17 apresentamos os dados referentes à interpretação da categoria de ação docente 'Sugere' e as cinco subcategorias: 'Sugere aos alunos o cálculo que deve ser realizado para a resolução da atividade do OA', 'Sugere aos alunos possíveis estratégias de resoluções para a atividade do OA', 'Sugere aos alunos que mudem de estratégia durante a realização da atividade do OA', 'Sugere aos alunos que realizem o cálculo antes de arriscar uma resposta para a atividade do OA' e 'Sugere aos alunos sobre a forma de iniciar a atividade do OA'.

Quadro 17 - Categorias e subcategorias de ações discentes relativas à categoria 'Sugere'.

\begin{tabular}{|c|c|}
\hline Categorias de ações discentes & Subcategorias de ações discentes \\
\hline Aceita ou não & $\begin{array}{l}\text { Aceitam ou não as sugestões do parceiro de dupla e dos outros alunos de estratégias de } \\
\text { resolução para a atividade do OA. } \\
\text { Aceitam ou não as sugestões do professor de cálculo que devem realizar para a } \\
\text { resolução da atividade do OA. } \\
\text { Aceitam ou não as sugestões do professor de estratégias de resolução para a atividade } \\
\text { do OA. } \\
\text { Aceitam ou não as sugestões do professor de proceder às mudanças de estratégias } \\
\text { durante a realização da atividade do OA. } \\
\text { Aceitam ou não as sugestões do professor de realizarem cálculos antes de arriscar uma } \\
\text { resposta para a atividade do OA. } \\
\text { Aceitam ou não as sugestões do professor sobre a forma de iniciar a atividade do OA. }\end{array}$ \\
\hline Apaga & Apagam os registros do quadro negro. \\
\hline Arrasta & $\begin{array}{l}\text { Arrastam objetos com a caneta digital no modo 'interativo'. } \\
\text { Arrastam objetos com o mouse do ultrabook. }\end{array}$ \\
\hline Arrisca & Arriscam uma resposta para a atividade do OA. \\
\hline Auxilia & $\begin{array}{l}\text { Auxiliam o parceiro de dupla e os outros alunos na atividade do OA. } \\
\text { Auxiliam o parceiro de dupla e os outros alunos nos conteúdos do OA. }\end{array}$ \\
\hline Comemora & Comemoram os acertos. \\
\hline Confere & $\begin{array}{l}\text { Conferem a resposta da atividade do OA com a caneta digital no modo 'interativo'. } \\
\text { Conferem a resposta da atividade do OA com o mouse do ultrabook. }\end{array}$ \\
\hline Desenha & Desenham no quadro negro. \\
\hline Discute & $\begin{array}{l}\text { Discutem diferentes estratégias de resolução para a atividade do OA com o parceiro de } \\
\text { dupla e os outros alunos. } \\
\text { Discutem possíveis soluções com o parceiro de dupla e os outros alunos. } \\
\text { Discutem possíveis soluções com o professor. }\end{array}$ \\
\hline Incentiva & $\begin{array}{l}\text { Incentivam o parceiro de dupla e os outros alunos a buscarem diferentes estratégias de } \\
\text { resolução para a atividade do OA. } \\
\text { Incentivam o parceiro de dupla e os outros alunos a realizarem a atividade do OA. }\end{array}$ \\
\hline Indica & $\begin{array}{l}\text { Indicam o erro cometido ao parceiro de dupla e aos outros alunos durante a realização } \\
\text { da atividade do OA. }\end{array}$ \\
\hline Inicia & Iniciam a atividade do OA. \\
\hline Observa & $\begin{array}{l}\text { Observam o parceiro de dupla e os outros alunos realizarem a atividade do OA. } \\
\end{array}$ \\
\hline Presta atenção & $\begin{array}{l}\text { Prestam atenção na atividade do OA através da área de projeção da LD. } \\
\text { Prestam atenção na atividade do OA através da tela do ultrabook. }\end{array}$ \\
\hline Realiza & $\begin{array}{l}\text { Realizam a atividade do OA com a caneta digital no modo 'interativo'. } \\
\text { Realizam a atividade do OA com o mouse do ultrabook. } \\
\text { Realizam cálculos mentalmente. } \\
\text { Realizam cálculos no quadro negro. }\end{array}$ \\
\hline Seleciona & $\begin{array}{l}\text { Selecionam a atividade do OA com a caneta digital no modo 'interativo'. } \\
\text { Selecionam a atividade do OA com o mouse do ultrabook. } \\
\text { Selecionam a resposta da atividade do OA com a caneta digital no modo 'interativo'. } \\
\text { Selecionam a resposta da atividade do OA com o mouse do ultrabook. } \\
\text { Selecionam o nível de dificuldade da atividade do OA com a caneta digital no modo } \\
\text { 'interativo'. } \\
\text { Selecionam o nível de dificuldade da atividade do OA com o mouse do ultrabook. }\end{array}$ \\
\hline Sugere & $\begin{array}{l}\text { Sugerem estratégias de resolução para a atividade do OA ao parceiro de dupla e aos } \\
\text { outros alunos. }\end{array}$ \\
\hline 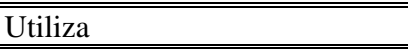 & "Utilizam diferentes estratégias de resolução para a atividade do OA. \\
\hline
\end{tabular}

Fonte: Autores.

A categoria de ação docente 'Sugere' propiciou o aparecimento de 38 ações discentes (coluna 2 do Quadro 17) - 
subcategorias de ações discentes - distintas que foram agrupadas em 18 categorias de ações discentes.

Apresentamos algumas colocações do professor que são representativas das ações de sugerir aos alunos possíveis estratégias de resoluções para a atividade do OA, que mudem de estratégia durante a realização da atividade, bem como sugerir o cálculo que deve ser realizado, expostas na sequência: "Vocês devem tentar utilizar outras formas de figuras e não somente retângulos"; "Se vocês usarem apenas um tipo de figura, vai acabar; e daí vocês não vão conseguir resolver"; "Conta quanto tem de área essa figura"; "Faz uma multiplicação para encontrar a área da figura"; que, em sua grande maioria, foram aceitas pelos alunos, levando-os a utilizarem diferentes estratégias que propiciaram a resolução correta das atividades do OA por eles.

No que concerne à subcategoria 'Valoriza a participação dos alunos', acomodada na categoria de ação docente 'Valoriza', a mesma propiciou o surgimento das categorias e subcategorias de ações discentes, apresentadas no Quadro 18.

Quadro 18 - Categorias e subcategorias de ações discentes relativas à categoria 'Valoriza'.

\begin{tabular}{|l|l||}
\hline Categorias de ações discentes & \multicolumn{1}{c|}{ Subcategorias de ações discentes } \\
\hline \hline Comemora & Comemoram os acertos. \\
\hline \hline Participa & Participam da atividade do OA. \\
\hline
\end{tabular}

Fonte: Autores.

Em relação ao posicionamento do docente referente à valorização da participação dos alunos, evidenciada na categoria de ação docente 'Valoriza', constatamos que essa ação partiu da iniciativa espontânea do professor, sendo uma atitude que se mostrou indispensável para manter, durante as três aulas analisadas, o interesse dos alunos que permaneceu centrado na realização da atividade do OA explorado.

Ainda, não podemos deixar de considerar que esse recurso proporcionou diversos desafios aos alunos e um ambiente visualmente atrativo, sendo essas condições, segundo nossas concepções, igualmente responsáveis pela motivação dos alunos, mantendo-os focados na exploração da atividade.

Ainda, no que concerne à subcategoria de ação discente 'Comemoram os acertos' (externalizadas pelos alunos por meio de 'aplausos' e 'gritos'; também utilizaram expressões como, por exemplo: "Viva!” e "Eba!”, ou seja, fizeram uso de interjeições que expressam sentido de alegria ou satisfação), a referida ação esteve presente em todo o decurso das três aulas analisadas, o que nos pareceu, também, incentivada pelos sons, imagens e mensagens motivadores do próprio OA explorado pelos investigados.

Por último, chegamos à conclusão de que os dados interpretados, ainda, possibilitou-nos identificar duas categorias de ações discentes - 'Mexe' e 'Sente interesse' - que não possuem inter-relação com as ações docentes e, por conseguinte, foram subcategorizadas da seguinte maneira: 'Mexem no celular' e 'Sentem interesse pelas figuras irregulares da atividade do OA'. No tocante à primeira subcategoria, consideramos que tal ação, no decorrer do processo analítico que realizamos não nos pareceu ter relação direta com a realização da atividade do OA, contudo, foi propiciada pelo ambiente de aprendizagem no qual os alunos utilizaram um recurso tecnológico. Apesar dessa ação específica não parecer ter sido fundamental na realização da atividade, a mantivemos como subcategoria pelo fato de que a mesma foi capaz de provocar algumas alterações no funcionamento da sala de aula, no decorrer da exploração do OA pelos sujeitos investigados. Em conclusão, enfatizamos que essas ações discentes, aqui destacadas e apresentadas como subcategorias de ações discentes, nos pareceram não ter despontado em decorrência de uma ação docente.

\section{Considerações Finais}

No presente artigo caracterizamos as ações docentes e discentes mediante a análise de um conjunto de dados que foram coletados com quatorze alunos do $7^{\circ}$ ano do Ensino Fundamental que exploraram, conjuntamente com um professor que 
ensina Matemática, um OA - na LD e no ultrabook - utilizados como recursos para o ensino e a aprendizagem de Matemática, ou seja, fazendo uso de tecnologias nas aulas de Matemática.

Em decorrência dos procedimentos da Análise de Conteúdo ao qual elegemos, nesta pesquisa, como uma proposta teórica utilizada como método de coleta e de análise de dados qualitativos, propiciou-nos a evidenciar 145 diferentes subcategorias que representam ações docentes (54) e discentes (91), acomodadas em 20 categorias de ações docentes 'Auxilia', 'Comenta', 'Coordena', 'Demonstra', 'Discute', 'Espera', 'Explica', 'Expõe’, 'Incentiva', 'Indica', 'Liga', 'Pergunta', 'Presta atenção', 'Projeta', 'Realiza', 'Resolve', 'Responde', 'Solicita', 'Sugere' e 'Valoriza' - e 30 categorias de ações discentes - 'Aceita ou não', 'Apaga', 'Arrasta', 'Arrisca', 'Auxilia', 'Comemora', 'Confere’, 'Desenha', 'Discute', 'Escuta', 'Espera', 'Fala', 'Incentiva', 'Indica', 'Inicia', 'Justifica', 'Mexe', 'Observa', 'Organiza', 'Participa', 'Pergunta', 'Presta atenção', 'Realiza', 'Responde’, 'Seleciona', 'Sente interesse’, 'Solicita auxílio’, 'Solicita explicação’, 'Sugere’ e 'Utiliza' - consideradas como resultantes de aulas fundamentadas na exploração de um OA através da LD e do ultrabook.

Ao confrontarmos as categorias evidenciadas, por meio desta pesquisa, com aquelas desveladas em investigações desenvolvidas por: Andrade e Arruda (2017) que categorizaram as ações docentes decorrentes de aulas expositivas; Dias, Arruda, Oliveira e Passos (2017) em que os autores dedicaram-se à categorização das ações docentes resultantes de aula baseada em atividade com o uso de materiais didáticos manipuláveis; e Benicio, Arruda e Passos (2019) na qual categorizaram as ações discentes decorrentes de aulas expositivas; constatamos que as aulas fundamentadas na utilização de tecnologias em aulas de Matemática - mais precisamente na utilização de OA explorados por meio de uma LD e um ultrabook - geraram uma quantidade expressiva de categorias de ações docentes e discentes em comparação com as demais investigações; fato também já comprovado por meio de outras pesquisas que desenvolvemos como, por exemplo, em: Vicentin, Passos e Arruda (2019, 2020).

Ainda, utilizando a mesma comparação anteriormente instituída corroboramos que as categorias de ações docentes, evidenciadas nesta pesquisa, 'Espera' e 'Explica' são comuns às investigações desenvolvidas por Andrade e Arruda (2017); Dias, Arruda, Oliveira e Passos (2017); Vicentin, Passos e Arruda (2019, 2020). As categorias de ações docentes 'Pergunta' e 'Responde' são encontradas unicamente nos trabalhos realizados por Dias, Arruda, Oliveira e Passos (2017); Vicentin, Passos e Arruda $(2019,2020)$. No que se refere às categorias de ações discentes, a categoria 'Espera' evidenciada nesta pesquisa também emergiu no trabalho realizado por Benicio, Arruda e Passos (2019), sendo empregado com a mesma significação; e nas pesquisas realizadas por Vicentin, Passos e Arruda $(2019$, 2020) que empregaram a mesma metodologia utilizada nesta investigação. Destacamos, também, que na investigação desenvolvida por Benicio, Arruda e Passos (2019) despontou a categoria 'Organiza' que compreendeu ações relativas às questões burocráticas e normativas e à organização de sala de aula e das atividades realizadas no decurso da aula; portanto sendo empregada em sentido distinto desta pesquisa que a considerou como uma ação relativa à organização dos alunos no decorrer da realização da atividade.

Além disso, referente às categorias de ações docentes - 'Espera', 'Liga', 'Projeta' 'Resolve' - e as subcategorias referentes a elas - 'Espera ocorrer a conexão entre os equipamentos (projetor, receptor da LD e ultrabook)', 'Liga os equipamentos (projetor, receptor da LD e ultrabook)', 'Projeta a atividade do OA através da LD', 'Resolve problemas técnicos ocorridos com a conexão dos equipamentos (projetor, receptor da LD e ultrabook)' - evidenciadas nesta pesquisa, ressaltamos que são ações relacionadas às questões técnicas dos recursos tecnológicos e, logo, não possuem inter-relação com a metodologia empregada pelos pesquisadores, no entanto, são ações indispensáveis e necessárias para a utilização do recurso um OA - pelos alunos e professor para o ensino e a aprendizagem da Matemática.

O processo de análise utilizado nesta pesquisa, também, nos possibilitou a confirmar a veracidade daquilo que constatamos em investigações anteriores que realizamos, podendo, dessa maneira, reafirmarmos e legitimarmos que para um conjunto de ações docentes geralmente há um desencadeamento de ações discentes correspondentes. 
Findamos esse artigo esclarecendo que as intervenções realizadas e aqui apresentadas, assim como, demais pesquisas que desenvolvemos - em que alunos do Ensino Fundamental e Médio e professor de Matemática são sujeitos investigados amplamente divulgadas, levaram-nos a conjecturar uma nova questão de pesquisa cujo foco de análise estará voltado para a evidenciação das conexões existentes entre as ações docente e discentes, investigações essas que serão disseminadas futuramente por meio da publicação de artigos científicos.

\section{Referências}

Andrade, E. C., \& Arruda, S. de M. (2017). Categorias das ações didáticas do professor de Matemática em sala de aula. Acta Scientiae, 19(2), 254-276. http://www.periodicos.ulbra.br/index.php/acta/article/viewFile/2819/2302.

Bardin, L. (2011). Análise de conteúdo. Edições 70.

Battistella, P. E., Neto, A. C. R., Campos, R. L. R., Inácio, A. S., Junior, D. I. R., Silveira, R. A., \& Von Wangenheim, A. (2009). Classificação de Objetos de Aprendizagem e Análise de Ferramentas de Autoria. In: Simpósio Brasileiro de Informática na Educação, XX, Florianópolis. Anais [...]. Santa Catarina: UFSC. 1-10. http://www.niee.ufrgs.br/eventos/SBIE/2009/conteudo/artigos/completos/62035_1.pdf.

Benicio, M. A, Arruda, S. de M., \& Passos, M. M. (2019). Um estudo das ações discentes em sala de aula de um campus do Instituto Federal do Paraná. Revista Brasileira de Pesquisa em Educação em Ciências, 19, 595-621. https://periodicos.ufmg.br/index.php/rbpec/article/view/13577.

Bianchini, E. (2015). Matemática Bianchini (8a ed.). Moderna. (Coleção $6^{\circ}$ ao $9^{\circ}$ ano).

Dias, M. P., Arruda, S. de M., Oliveira, A. C. de, \& Passos, M. M. (2017). Relações com o ensinar e as categorias de ação do professor de matemática. Caminhos da Educação Matemática em Revista/Online, 7(2), 66-75. https://aplicacoes.ifs.edu.br/periodicos/index.php/caminhos_d a_educacao_matematica/article/view/144/133.

Ferreira, M. E. D., Oliveira, S. B., \& Coelho Neto, J. (2019). Objetos de Aprendizagem e o Ensino da Matemática: um mapeamento dos recursos utilizados em sala de aula. Research, Society and Development, 8(1), e4081629. https://doi.org/10.33448/rsd-v8i1.629.

Flick, U. (2009). Introdução à pesquisa qualitativa (J. E. Costa, Trad.) (3a ed.). Artmed.

Kalinke, M. A., \& Motta, M. S. (2019). Objetos de Aprendizagem: pesquisas e possibilidades na Educação Matemática. Ed. Life Editora.

Kenski, V. M. (2003). Tecnologias e ensino presencial e a distância (3a ed.). Papirus.

Libâneo, J. C. (1994). Didática. Editora Cortez.

Moraes, R. (1999). Análise de conteúdo. Revista Educação, 22(37), 7-32.

Navarro, E. R., \& Kalinke, M. A. (2018). Lousa digital: investigando o uso na rede estadual de ensino com o apoio de formação continuada. CRV.

Pereira, N. V., \& Araújo, M. S. T. de. (2020). Utilização de recursos tecnológicos na Educação: caminhos e perspectivas. Research, Society and Development, 9(8), e447985421. https://doi.org/10.33448/rsd-v9i8.5421.

Phet Interactive Simulations. (2019). https://phet.colorado.edu/pt_BR/simulations/category/math.

Rocha, E. M., \& Rodrigues, J. F. (2005). A Comunicação da Matemática na Era Digital. Boletim da SPM, 53, 1-21.

Silva, V. S. (2015). Tendências metodológicas em educação matemática: aproximações iniciais. Guarapuava. Repositório Unicentro. http://repositorio.unicentro.br:8080/jspui/bitstream/123456789/606/5/SILVA\%2C\%20V.S.\%20Tend\%C3\%AAncias\%20metodol\%C3\%B3gicas.pdf.

Vicentin, F. R., Passos, M. M., \& Arruda, S. de M. (2019). Ações de estudantes e professor que exploram um objeto de aprendizagem em aulas de matemática. In: Encontro Paranaense de Educação Matemática, XV, 2019, Londrina. Anais [...]. Paraná: UTFPR/UEL. 1-14. http://www.sbemparana.com.br/eventos/index.php/EPREM/XV_EPREM/paper/view/996/920.

Vicentin, F. R., Passos, M. M., \& Arruda, S. de M. (2020). Caracterização das ações de alunos e professor em aulas de matemática fundamentadas no uso de tecnologias. Revista Paranaense de Educação Matemática, 9(20), 62-88. http://www.fecilcam.br/revista/index.php/rpem/article/view/2311. 